ENVIRONMENTAL RESTORATION PROGRAM

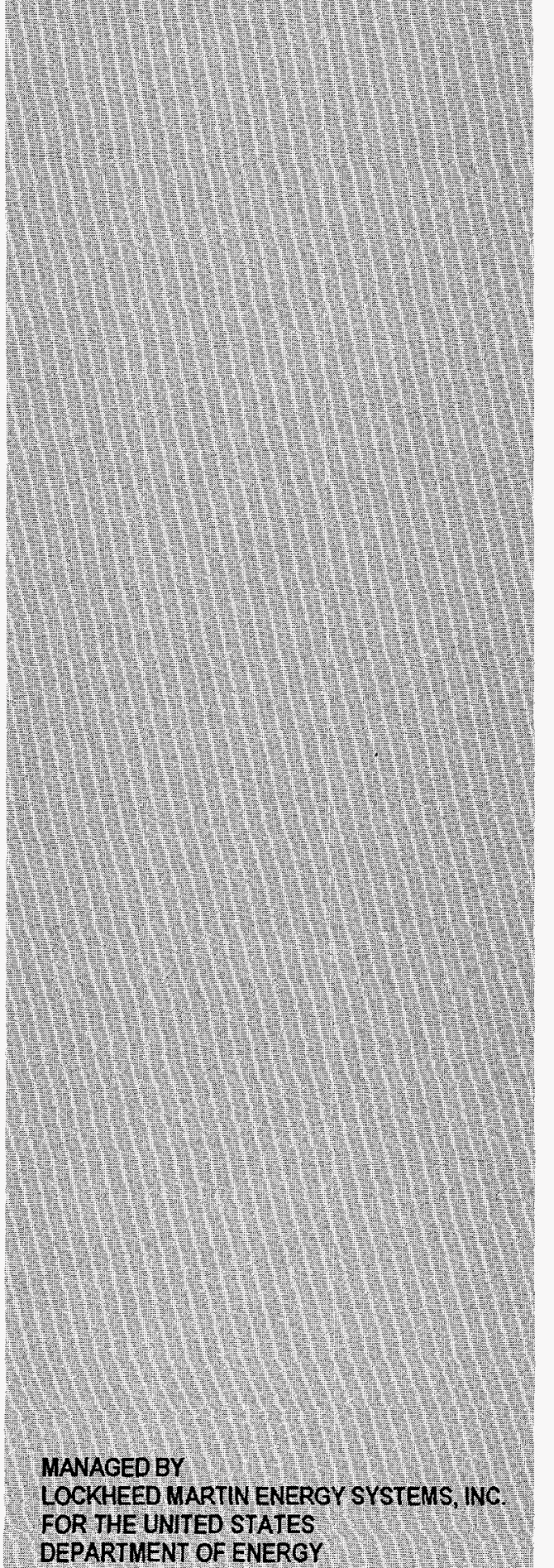

\title{
Final Deactivation Report
Radioisotope Production Lab-H, \\ Final Deactivation Report
on the Radioisotope Production Lab-H, Building 3118, at Oak Ridge National Laboratory, Ridge National Labor
Oak Ridge, Tennessee
}

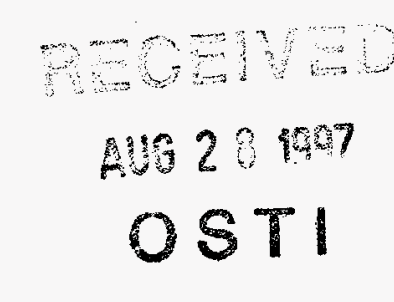

$$
\begin{gathered}
\text { AUS } 28 \text { 1907 } \\
\text { OSTI }
\end{gathered}
$$

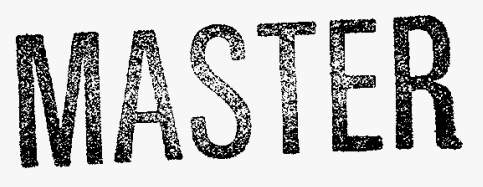

This document has been approved by the ORNL Technical Information Office for release to the public. Date: $8 / 12 / 97$ 

ORNL/ER-407

\title{
Final Deactivation Report on the Radioisotope Production Lab-H, Building 3118, at Oak Ridge National Laboratory, Oak Ridge, Tennessee
}

Date Issued-August 1997

\author{
DISTRIBUTION OF THIS DOCUMENT IS UNLIMITED \\ Prepared for the \\ U.S. Department of Energy \\ Office of Environmental Management \\ under budget and reporting code EW 20 \\ Environmental Management Activities at the \\ OAK RIDGE NATIONAL LABORATORY \\ Oak Ridge, Tennessee 37831 \\ managed by \\ LOCKHEED MARTIN ENERGY SYSTEMS, INC. \\ for the \\ U.S. DEPARTMENT OF ENERGY \\ under contract DE-AC05-84OR21400
}

\section{DISCLAIMER}

\begin{abstract}
This report was prepared as an account of work sponsored by an agency of the United States Government. Neither the United States Gnvernment nor any agency thereof, nor any of their employees, makes any warranty, express or implied, or assumes any legal liability or responsibility for the accuracy, completeness, or usefulness of any information, apparatus, product, or process disclosed, or represents that its use would not infringe privately owned rights. Reference herein to any specific commercial product, process, or service by trade name, trademark, manufacturer, or otherwise does not necessarily constitute or imply its endorsement, recommendation, or favoring by the United States Government or any agency thereof. The views and opinions of authors expressed herein do not necessarily state or reflect those of the United States Government or any agency thereof.
\end{abstract}





\section{DISCLAMMER}

Portions of this document may be illegible in electronic image products. Images are produced from the best available original document. 



\section{PREFACE}

This is the Final Deactivation Project Report on the Radioisotope Production Lab-H, Building 3118, at Oak Ridge National Laboratory, Oak Ridge, Tennessee (ORNL/ER-407). Although this element of work is not part of the Comprehensive Environmental Response, Compensation, and Liability Act of 1980, it was accomplished in accordance with the substantive requirements of the Act. This work was performed under Work Breakdown Structure 1.6.6.2.10.02, Activity Data Sheet 6504IS, "Isotopes Facilities Deactivation Project." This document provides the Environmental Management and Enrichment Facilities Program with the final report on the deactivation of Bldg. 3118 . 



\section{CONTENTS}

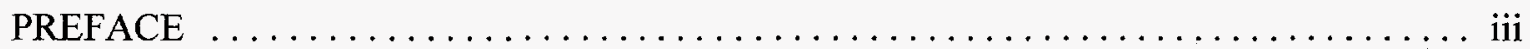

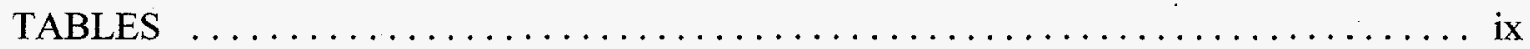

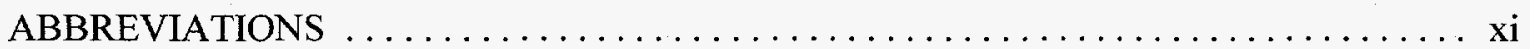

DEFINITIONS $\ldots \ldots \ldots \ldots \ldots \ldots \ldots \ldots \ldots \ldots \ldots \ldots \ldots \ldots \ldots \ldots \ldots \ldots \ldots \ldots \ldots \ldots \ldots \ldots \ldots$

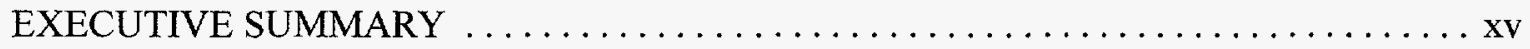

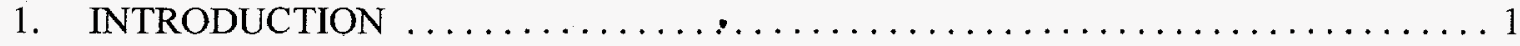

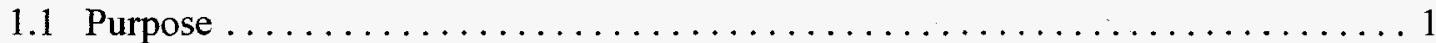

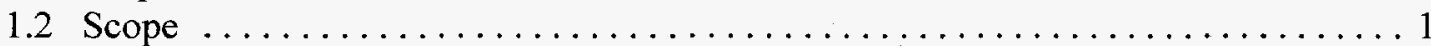

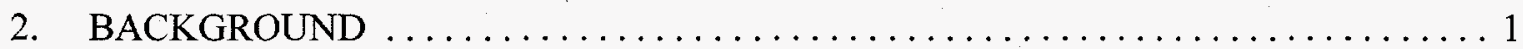

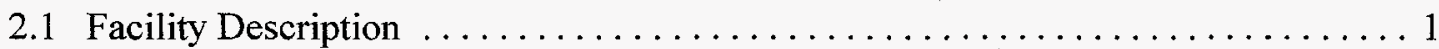

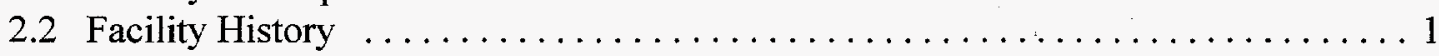

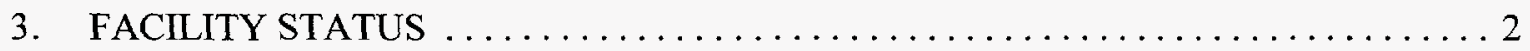

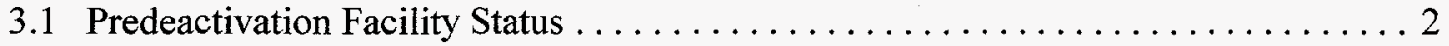

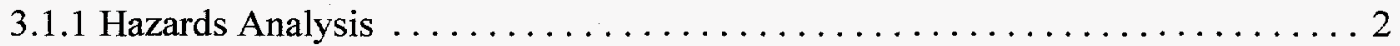

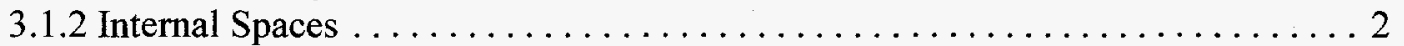

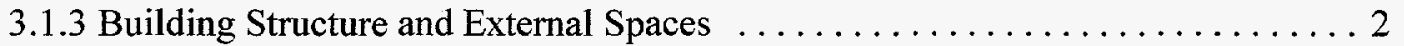

3.1.4 Process, Utility, and Support Systems ...................... 2

3.1.5 Radioactive Material, Contamination, and Waste $\ldots \ldots \ldots \ldots \ldots \ldots \ldots \ldots$

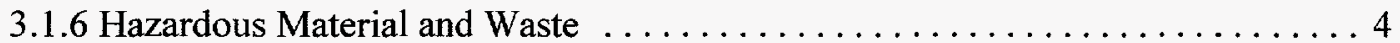

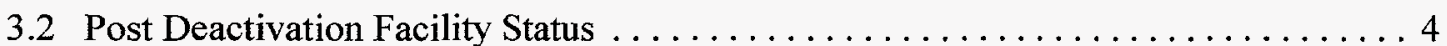

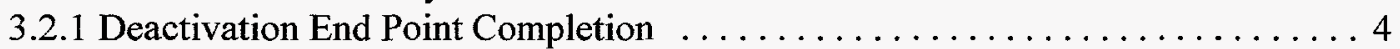

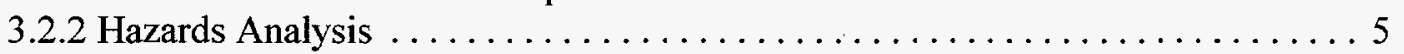

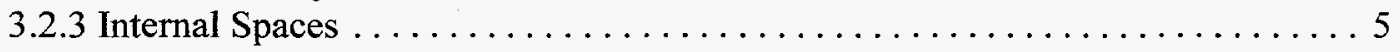

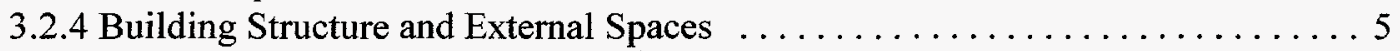

3.2 .5 Process, Utility, and Support Systems . . . . . . . . . . . . . . 5

3.2.6 Radioactive Material, Contamination, and Waste $\ldots \ldots \ldots \ldots \ldots \ldots \ldots$

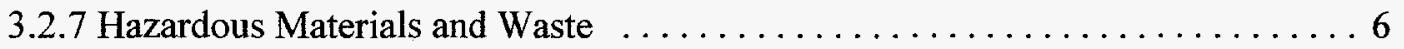

4. Bldg. 3118 DEACTIVATION ACTIVITIES $\ldots \ldots \ldots \ldots \ldots \ldots \ldots \ldots \ldots \ldots \ldots$

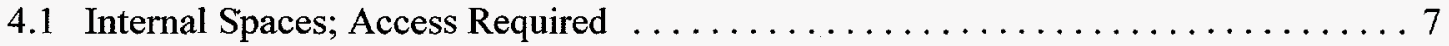

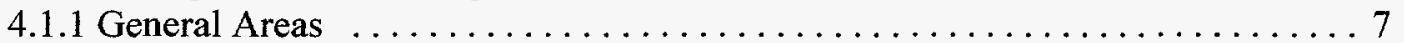

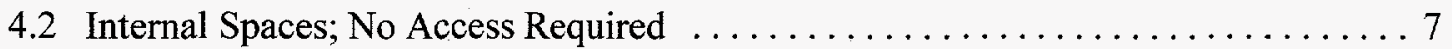

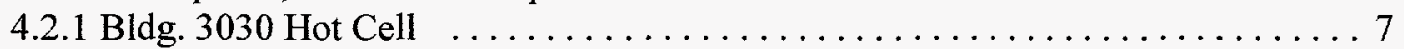

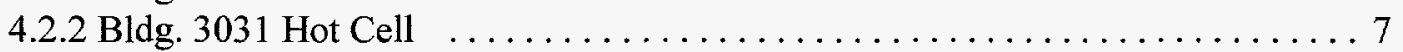

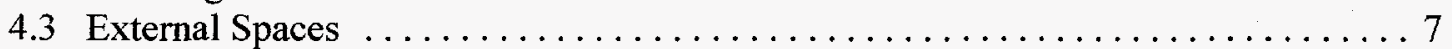

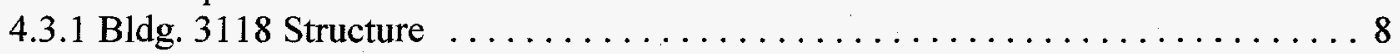

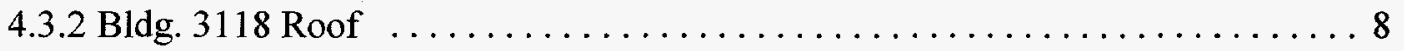




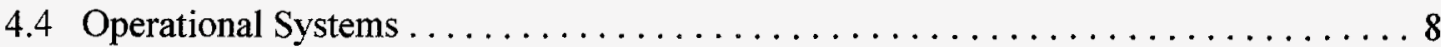

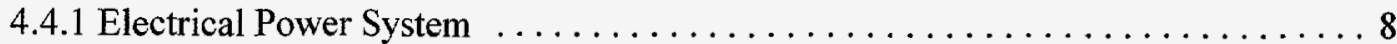

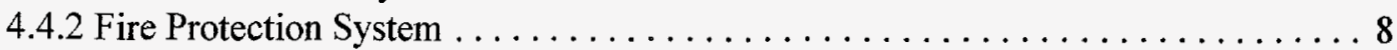

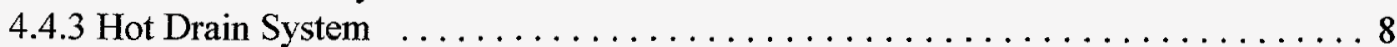

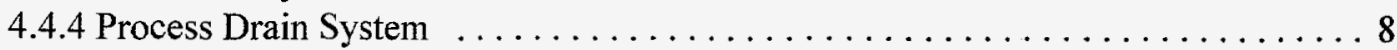

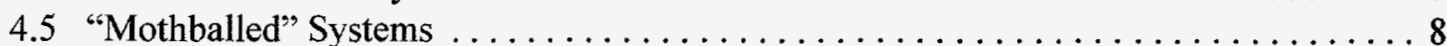

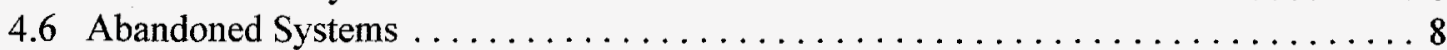

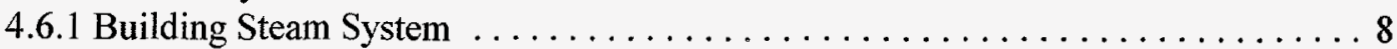

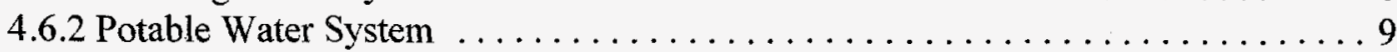

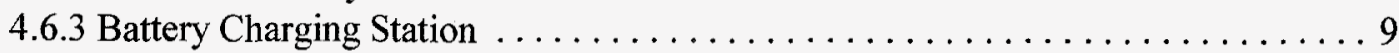

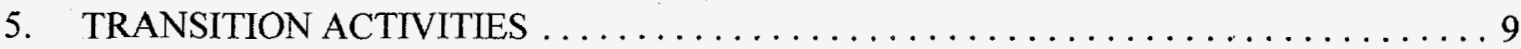

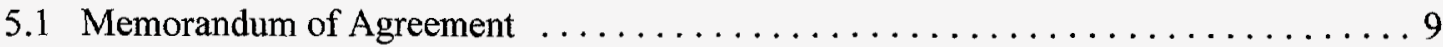

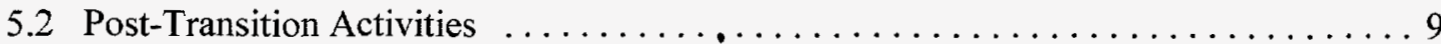

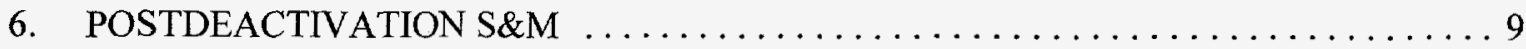

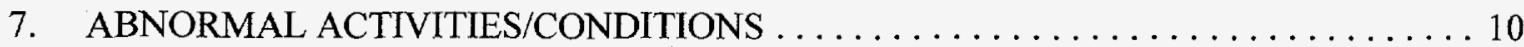

8. TURNOVER PACKAGE DOCUMENTATION $\ldots \ldots \ldots \ldots \ldots \ldots \ldots \ldots \ldots \ldots \ldots$

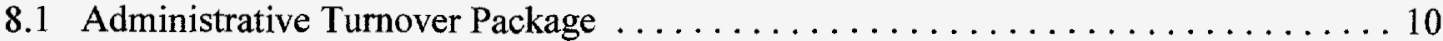

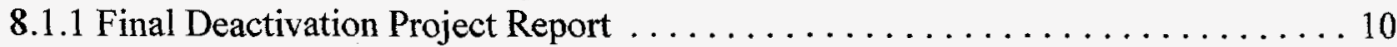

8.1.2 Regulatory Compliance Documentation $\ldots \ldots \ldots \ldots \ldots \ldots \ldots \ldots \ldots \ldots \ldots \ldots \ldots$

8.1.3 Interagency Agreements Documentation . . . . . . . . . . . . . . . 10

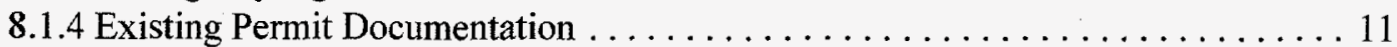

8.1.5 Corrective Action Documentation . . . . . . . . . . . . . . . . . . . 11

8.1.6 Deactivation Locks and Keys . . . . . . . . . . . . . . . . . . . . 11

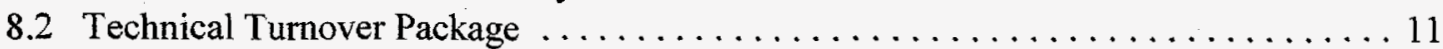

8.2.1 Updated Facility Drawings (Arrangements, PID, Loop, Etc.) . . . . . . . . . . . 11

8.2.2 "As Left" Photos of Spaces and Major Equipment . . . . . . . . . . . . . 12

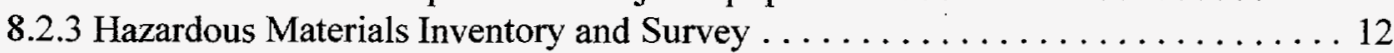

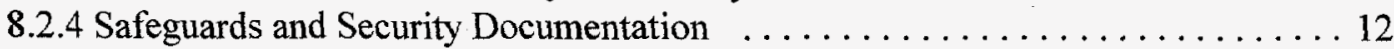

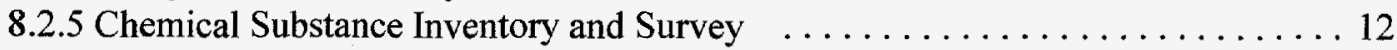

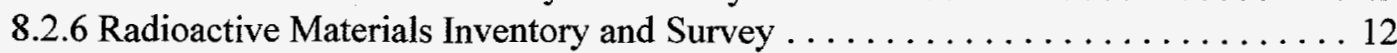

8.2.7 Facility Soil, Surface Water, and Groundwater Condition Report . . . . . . 12

8.3 S\&M Turnover Package . . . . . . . . . . . . . . . . . . . . . 12

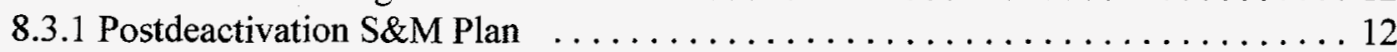

8.3.2 Postdeactivation S\&M Updated Safety Equipment List . . . . . . . . . 13

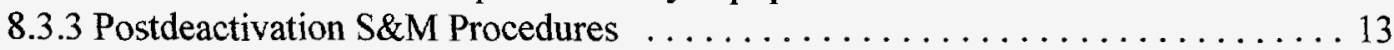

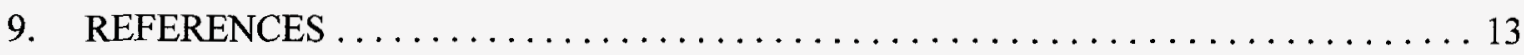

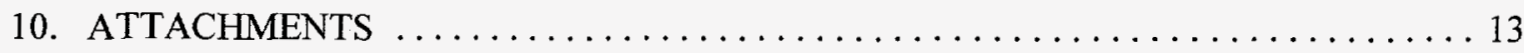

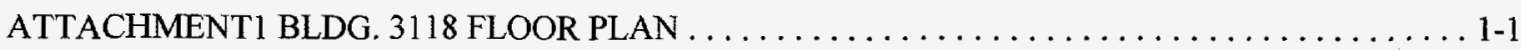

ATTACHMENT 2 BLDG. 3118 PREDEACTIVATION FACILITY PHOTOGRAPHS $\ldots \ldots \ldots \ldots 2-1$ 
ATTACHMENT 3 BLDG. 3118 POSTDEACTIVATION FACILITY PHOTOGRAPHS

ATTACHMENT 4 ADMINISTRATIVE TURNOVER PACKAGE CHECKLIST

ATTACHMENT 5 TECHNICAL TURNOVER PACKAGE CHECKLIST

ATTACHMENT 6 BLDG. 3118 DRAWING LIST 6-1

ATTACHMENT 7 BLDG. 3118 RADIOLOGICAL SURVEY DATA $\ldots \ldots \ldots \ldots \ldots \ldots \ldots \ldots$ 7-1 ATTACHMENT 8 S\&M TURNOVER PACKAGE CHECKLIST 8-1 



\section{TABLES}

1. Predeactivation Radioactive Contamination Levels $\ldots \ldots \ldots \ldots \ldots \ldots \ldots \ldots \ldots \ldots .4$

2. Predeactivation Radiation Levels $\ldots \ldots \ldots \ldots \ldots \ldots \ldots \ldots \ldots \ldots \ldots \ldots$

3. Bldg. 3118 Predeactivation Hazardous Materials and Waste $\ldots \ldots \ldots \ldots \ldots \ldots \ldots \ldots$.

4. Postdeactivation Radioactive Contamination Levels $\ldots \ldots \ldots \ldots \ldots \ldots \ldots \ldots \ldots \ldots$

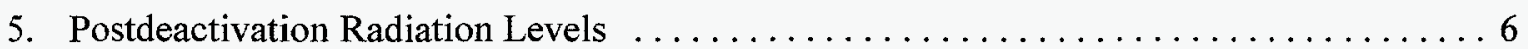

6. Bldg. 3118 Postdeactivation Hazardous Materials and Waste $\ldots \ldots \ldots \ldots \ldots \ldots \ldots \ldots$

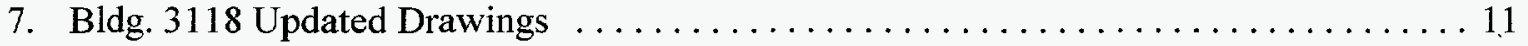





\section{ABBREVIATIONS}

DOE

EM-40

EM-60

FDPR

MOA

ORNL

S\&M
U.S. Department of Energy

Department of Energy Office of Environmental Restoration

Department of Energy Office of Facility Transition and Management

Final Deactivation Project Report

Memorandum of Agreement

Oak Ridge National Laboratory

Surveillance and Maintenance 



\section{DEFINITIONS}

Commitments

Deactivation

Decommissioning

Decontamination

Defense-in-Depth

End Point

End Point Technical Information

Stakeholder

Turnover Package
Tasks required to be accomplished to meet nonregulatory requirements (site, stakeholders, etc.)

The process of placing a facility in a safe and stable condition to minimize the long-term cost of a surveillance and maintenance program that is protective of workers, the public, and the environment until decommissioning is completed.

Refers to the ultimate disposition of a facility. Also substitutes for previously used "D\&D."

The removal or reduction of radioactive or hazardous contamination from facilities, equipment, or soils by washing, heating, chemical or electro-chemical action, mechanical cleaning or other techniques to achieve a stated objective or end condition.

Achieving required levels of safety and protection there is more than one layer of protection between the hazard and that which is being protected.

A detailed specification for the final deactivation condition of areas and hardware within a facility and related documentation. An individual milestone towards the deactivation and/or the decommissioning of a facility.

A compilation of documents to support end point conclusions.

Individuals and organizations (i.e., regulators, local municipalities, the public, etc.) who may be directly or indirectly impacted by activities associated with the Isotopes Facilities Deactivation Project.

A compilation of project related documents to be given to a postdeactivation organization. 



\section{EXECUTIVE SUMMARY}

The purpose of this report is to document the condition of Bldg. 3118 , after completion of deactivation activities as outlined by the Department of Energy (DOE) Office of Nuclear Materials and Facility Stabilization Program (EM-60) guidance documentation. This report outlines the activities conducted to place the facility in a safe and environmentally sound condition for transfer to the DOE Office of Environmental Restoration Program (EM-40).

This report provides a history and profile of Bldg. 3118 prior to commencing deactivation activities and a profile of the building after completion of deactivation activities. Turnover items, such as the Postdeactivation Surveillance \& Maintenance Plan, remaining hazardous materials, radiological controls, Safeguards and Security, quality assurance, facility operations, and supporting documentation provided in the Office of Nuclear Materials and Facility Stabilization Program (EM-60) Turnover package are discussed.

Building 3118 will require access to facilitate required S\&M activities to maintain the building safety envelope. Building 3118 was stabilized during deactivation so that when transferred to the EM-40 program, only a minimal S\&M effort would be required to maintain the building safety envelope. Other than the minimal S\&M activities the building will be unoccupied and the exterior doors locked to prevent unauthorized access. The building will be entered only to perform the required $S \& M$.

All materials have been removed from the building and all utility systems, piping, and alarms have been deactivated. 


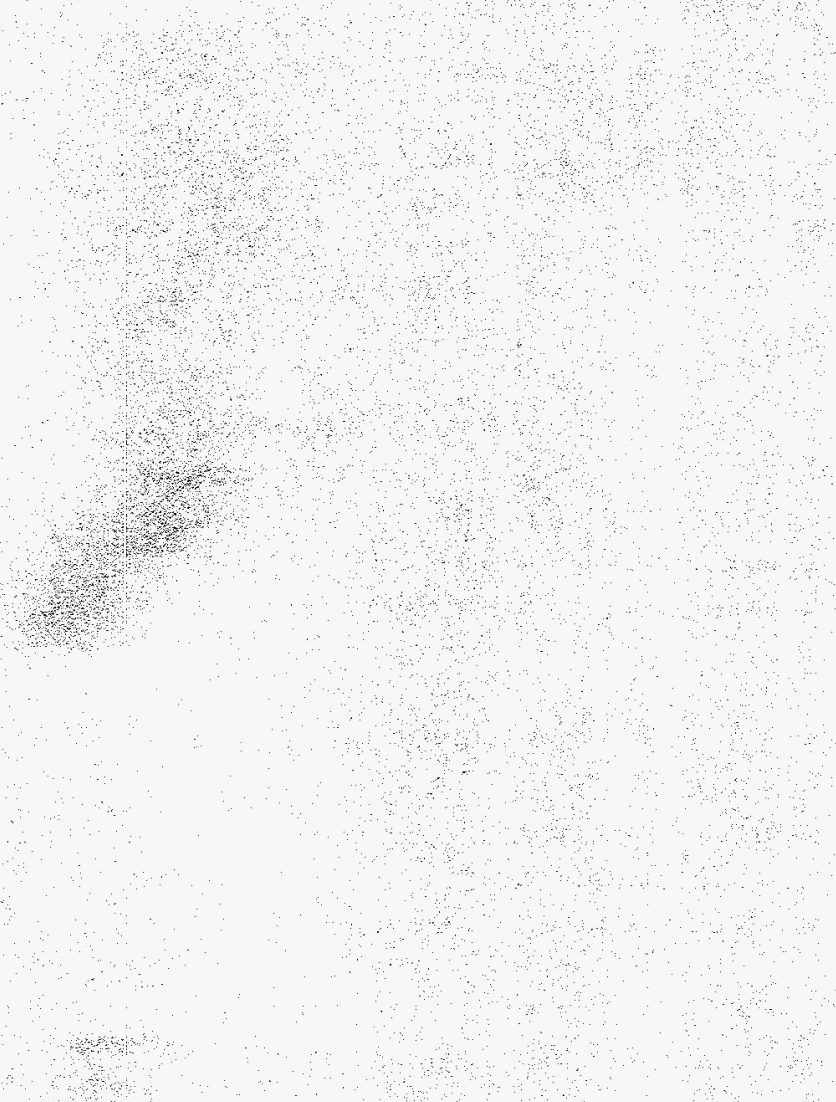




\section{INTRODUCTION}

\subsection{PURPOSE}

The purpose of this report is to document the condition of Bldg. 3118 after completion of deactivation activities as outlined by the Department of Energy (DOE) Office of Nuclear Materials and Facility Stabilization (EM-60) Program guidance documentation. This report outlines the activities conducted to place the facility in a safe and environmentally sound condition for transfer to DOE's Office of Environmental Restoration (EM-40) Program.

This report provides a profile of the facility before and after deactivation activities. Turnover items, such as the Postdeactivation Surveillance \& Maintenance Plan, remaining hazardous materials, radiological controls, Safeguards and Security, QA, facility operations, and supporting documentation provided in the EM-60 Turnover package are also discussed.

\subsection{SCOPE}

This report addresses the activities performed during deactivation to place Bldg. 3118 in a safe and environmentally sound condition to await decommissioning and discusses the status of the facility and the activities required to maintain the facility following deactivation. Attachment 1 , "Building 3118 Floor Plan," provides a floor plan of Bldg. 3118 that illustrates the physical boundaries and scope of this Final Deactivation Project Report (FDPR). The scope of this FDPR is limited to Bldg. 3118.

\section{BACKGROUND}

\subsection{FACILITY DESCRIPTION}

Building 3118 is located in the west central area of the Isotope Circle in the Oak Ridge National Laboratory (ORNL) Isotopes Area, north of Bldg. 3038. The facility is a steel frame structure, covered by corrugated aluminum siding, that was erected by roofing and enclosing the space between Bldgs. 3030 and 3031 . Building 3118 provides access to the rear entry doors for the hot cells in Bldgs. 3030 and 3031 . Building 3118 also provided general storage space, forklift storage, and temporary storage for contaminated waste.

\subsection{FACILITY HISTORY}

Building 3118 was constructed in the early 1960 s to enclose the access to the rear entry doors for the hot cells in Bldgs. 3030 and 3031 . Building 3118 provided a charging station and storage location for battery-powered forklifts and has also functioned as a storage shed for drums and containers of hazardous and radiological waste, radioactive shielding materials, and casks. 
The primary purpose for Bldg. 3118 was to enclose the rear access areas to the hot cells in Bldgs. 3030 and 3031 . Maintenance, decontamination, and process activities requiring access to the hot cells were conducted from within Bldg. 3118 .

\section{FACILITY STATUS}

\subsection{PREDEACTIVATION FACILITY STATUS}

Following approximately 30 years of operational support activities, Bldg. 3118 was surplused. General housekeeping was not maintained, and the building structural integrity was allowed to lapse.

Attachment 2, "Predeactivation Facility Photographs," contains photographs of the building conditions prior to deactivation activities.

\subsubsection{Hazards Analysis}

No predeactivation hazards analysis was performed. Since no process activities were performed in Bldg. 3118, it was determined that the facility did not warrant a hazard analysis/safety analysis.

\subsubsection{Internal Spaces}

The general area contained furniture, cabinets, hazardous waste, radioactive waste, a fork lift, and various miscellaneous items used when the facility was in operation. The lead-based paint is chipping and peeling, providing a means of transferring contamination and endangering personnel and the environment.

Predeactivation radioactive contamination levels and radiation levels for the general area are listed in Tables 1 and 2, respectively. Table 3 lists predeactivation hazardous materials and waste located in the general area.

\subsubsection{Building Structure and External Spaces}

The structure and roof of Bldg. 3118 were inspected and found to be in generally good condition, with the exception of water inleakage through various paths.

\subsubsection{Process, Utility and Support Systems}

\subsubsection{Electrical power system}

Prior to deactivation the electrical power system provide power and distribution for the 480 VAC electrical service to Bldg. 3118. Typical electrical loads were the lighting, battery charger, heaters, and exhaust fans.

\subsubsection{Fire protection system}

Prior to deactivation, the fire protection system provided a dry pipe fire suppression system for Bldg. 3118. The general area was equipped with sprinkler heads and alarms as required by the local 
fire code. In addition, fire extinguishers were placed strategically in and around Bldg. 3118 . The fire protection system is not believed to be contaminated.

\subsubsection{Building steam system}

Prior to deactivation the building steam system provided steam for use in heating the general area of Bldg. 3118. Heat exchangers are located in Bldg. 3118; these provided space heating for personnel.

The building steam system is not believed to be contaminated. However, most of the steam piping within Bldg. 3118 is lagged with asbestos insulation materials.

\subsubsection{Potable water system}

Prior to deactivation, the potable water system provided water to the Bldg. 3118 safety shower, hot water heater, and sink. The potable water system is not believed to be contaminated.

\subsubsection{Hot drain system}

Prior to deactivation, the hot drain system provided a means of discharging liquid process wastes from the hot cells to the low-level liquid waste (LLLW) system. The hot drain system is a gravity drain system to the WC-10 tank in the ORNL LLLW system.

The hot drain system is highly contaminated from the process and cleaning activities performed prior to deactivation.

\subsubsection{Process drain system}

Prior to deactivation, the process drain system provided a means of removing liquids from the floor area to the ORNL Process Waste System and Treatment Facility. The process drain system is a gravity drain system.

The process drain system is contaminated from the process and cleaning activities performed prior to deactivation.

\subsubsection{Battery charging station}

A battery charging station located in the building provided DC electrical power for recharging fork lift batteries.

The battery charging station is not believed to be contaminated.

\subsubsection{Radioactive Material, Contamination, and Waste}

Table 1 lists the radioactive contamination levels identified on radiation surveys conducted prior to deactivation. 
Table 1. Predeactivation Radioactive Contamination Levels

\begin{tabular}{lll}
\hline \multicolumn{1}{c}{ Identification } & \multicolumn{1}{c}{ Description } & \multicolumn{1}{c}{ Quantity } \\
\hline General area & $\begin{array}{l}\text { beta/gamma smear - } \\
\text { transferable contamination }\end{array}$ & $\begin{array}{l}\text { less than } 200 \text { to } 791 \\
\text { dpm } / 100 \mathrm{~cm}^{2}\end{array}$ \\
Bldg. 3030 hot cell & beta/gamma smear - & less than 200 \\
exterior door area & transferable contamination & dpm $/ 100 \mathrm{~cm}^{2}$ \\
Bldg. 3031 hot cell & beta/gamma smear - & less than 200 \\
exterior door area & transferable contamination & dpm $/ 100 \mathrm{~cm}^{2}$ \\
\hline
\end{tabular}

Table 2 lists radiation levels identified on radiation surveys conducted prior to deactivation:

Table 2. Predeactivation Radiation Levels

\begin{tabular}{|c|c|c|}
\hline Identification & Description & Quantity \\
\hline General area & $\begin{array}{l}\text { fixed and transferable radiation } \\
\text { levels }\end{array}$ & $0.5 \mathrm{mRem} / \mathrm{hr}$ \\
\hline $\begin{array}{l}\text { Bldg. } 3030 \text { hot cell } \\
\text { exterior door area }\end{array}$ & $\begin{array}{l}\text { fixed and transferable radiation } \\
\text { levels }\end{array}$ & 3-6 mRem $/ \mathrm{hr}$ \\
\hline $\begin{array}{l}\text { Bldg. } 3031 \text { hot cell } \\
\text { exterior door area }\end{array}$ & $\begin{array}{l}\text { fixed and transferable radiation } \\
\text { levels }\end{array}$ & $10 \mathrm{mRem} / \mathrm{hr}$ \\
\hline
\end{tabular}

\subsubsection{Hazardous Materials and Waste}

Table 3 lists the hazardous materials and waste identified during facility walkdowns prior to deactivation.

Table 3. Bldg. 3118 Predeactivation Hazardous Materials and Waste

\begin{tabular}{lll}
\hline \multicolumn{1}{c}{ Identification } & \multicolumn{1}{c}{ Description } & \multicolumn{1}{c}{ Quantity } \\
\hline Lead-based paint & $\begin{array}{l}\text { Used as wall covering throughout } \\
\text { building. }\end{array}$ & indeterminate \\
Asbestos lagging & $\begin{array}{l}\text { Used as pipe lagging throughout the } \\
\text { building }\end{array}$ & indeterminate \\
PCBs & $\begin{array}{l}\text { Electrical devices and transformers } \\
\text { Lead shielding }\end{array}$ & indeterminate \\
\hline
\end{tabular}

\subsection{POST DEACTIVATION FACHLTY STATUS}

Attachment 3, "Postdeactivation Facility Photographs," contains photographs of the building conditions following deactivation activities.

\subsubsection{Deactivation End Point Completion}

End point criteria for deactivation activities and end point completion documentation are not applicable for Bldg. 3118. The requirement and guidance for these program elements were not developed prior to Bldg. 3118 deactivation. 


\subsubsection{Hazards Analysis}

No postdeactivation hazards analysis was performed. Since no process activities were performed in Bldg. 3118, it was determined that the facility did not warrant a hazard analysis/safety analysis.

\subsubsection{Internal Spaces}

The miscellaneous items abandoned when the facility was no longer in use have been removed from the general area, and no significant combustibles remain there. The general area of Bldg. 3118 was decontaminated to remove transferable contamination from access-required spaces. The leadbased paint is chipping and peeling, providing a means of transferring the lead contamination.

Postdeactivation radioactive contamination levels and radiation levels for this area are listed in Tables 4 and 5, respectively. Postdeactivation hazardous materials and waste located in this area are listed in Table 6.

\subsubsection{Building Structure and External Spaces}

The structure and roof of Bldg. 3118 were inspected and found to be in generally good condition, with the exception of water inleakage through various paths.

\subsubsection{Process, Utility, and Support Systems}

\subsubsection{Electrical power system}

All electrical services, with the exception of lighting, have been disconnected or de-energized at the main breaker box.

\subsubsection{Fire protection system}

The fire protection system for this building is a dry system and is available for use if there is a fire in the building.

\subsubsection{Building steam system}

The building steam system has been isolated, drained, and abandoned in place.

\subsubsection{Potable water system}

The potable water system has been isolated, drained, and abandoned in place.

\subsubsection{Hot drain system}

The hot drain system has been abandoned in place. All hot cell drains have been plugged to isolate the hot cells and to prevent the potential spread of contamination.

The hot drain system remains highly contaminated from the process and cleaning activities performed prior to deactivation. 


\subsubsection{Process drain system}

The process drain system has been abandoned in place. However, the process drain system remains connected to the ORNL process waste system. This system remains contaminated from the process and cleaning activities performed prior to deactivation.

\subsubsection{Battery charging station}

The battery charging station has been de-energized and abandoned in place.

\subsubsection{Radioactive Material, Contamination, and Waste}

Table 4 lists the radioactive contamination levels identified on radiation surveys conducted following deactivation.

Table 4. Postdeactivation Radioactive Contamination Levels

\begin{tabular}{lll}
\hline \multicolumn{1}{c}{ Identification } & \multicolumn{1}{c}{ Description } & \multicolumn{1}{c}{ Quantity } \\
\hline General area & $\begin{array}{l}\text { alpha smear - transferable } \\
\text { contamination } \\
\text { beta/gamma smear - } \\
\text { transferable contamination }\end{array}$ & $\begin{array}{l}\text { less than } 20 \\
\mathrm{dpm} / 100 \mathrm{~cm}^{2}\end{array}$ \\
General area & $\begin{array}{l}\text { less than } 200 \\
\mathrm{dpm} / 100 \mathrm{~cm}^{2}\end{array}$ \\
Bldg. 3030 hot cell & alpha smear - transferable & $\begin{array}{l}\text { less than } 20 \\
\mathrm{dpm} / 100 \mathrm{~cm}^{2}\end{array}$ \\
exterior door area & contamination & less than 200 \\
Bldg. 3030 hot cell & beta/gamma smear - & dpm/100 $\mathrm{cm}^{2}$ \\
exterior door area & transferable contamination & less than 20 \\
Bldg. 3031 hot cell & alpha smear - transferable & $\mathrm{dpm} / 100 \mathrm{~cm}^{2}$ \\
exterior door area & contamination & less than 200 \\
Bldg. 3031 hot cell & beta/gamma smear - \\
exterior door area & transferable contamination & dpm $/ 100 \mathrm{~cm}^{2}$ \\
\hline
\end{tabular}

Table 5 lists radiation levels identified on radiation surveys conducted following deactivation.

Table 5. Postdeactivation Radiation Levels

\begin{tabular}{|c|c|c|}
\hline Identification & Description & Quantity \\
\hline General Area & $\begin{array}{l}\text { fixed and transferable radiation } \\
\text { levels }\end{array}$ & $0.5 \mathrm{mRem} / \mathrm{hr}$ \\
\hline $\begin{array}{l}3030 \text { Hot Cell } \\
\text { exterior door area }\end{array}$ & $\begin{array}{l}\text { fixed and transferable radiation } \\
\text { levels }\end{array}$ & $3.0 \mathrm{mRem} / \mathrm{hr}$ \\
\hline $\begin{array}{l}3031 \text { Hot Cell } \\
\text { exterior door area }\end{array}$ & $\begin{array}{l}\text { fixed and transferable radiation } \\
\text { levels }\end{array}$ & $1.0 \mathrm{mRem} / \mathrm{hr}$ \\
\hline
\end{tabular}

\subsubsection{Hazardous Materials and Waste}

Table 6 lists the hazardous materials and waste identified during facility walkdowns following deactivation. 
Table 6. Bldg. 3118 Postdeactivation Hazardous Materials and Waste

\begin{tabular}{lll}
\hline \multicolumn{1}{c}{ Identification } & \multicolumn{1}{c}{ Description } & \multicolumn{1}{c}{ Quantity } \\
\hline Lead based paint & $\begin{array}{l}\text { Used as wall covering throughout } \\
\text { building. }\end{array}$ & indeterminate \\
Asbestos lagging & $\begin{array}{l}\text { Used as pipe lagging throughout the } \\
\text { building }\end{array}$ & indeterminate \\
PCBs & Electrical devices and transformers & indeterminate \\
\hline
\end{tabular}

\section{BLDG. 3118 DEACTIVATION ACTIVITIES}

The following section addresses the major activities performed during the deactivation of Bldg. 3118. The objectives of the deactivation process were to place the facility in a passively safe and environmentally stable configuration that can be efficiently and cost-effectively maintained indefinitely. The major deactivation issues regarding Bldg. 3118 are listed in the following sections.

\subsection{INTERNAL SPACES; ACCESS REQUIRED}

\subsubsection{General Area}

All storage cabinets, desks, file cabinets and miscellaneous office materials were removed from the building. Some were green-tagged for reuse. The remaining items were disposed of. Asbestos pipe insulation was not removed.

Lead-based paint covers the walls throughout the building. Peeling and flaking areas have been repaired, but the remainder of the paint will remain as is. Paint condition is an inspection item in the surveillance and maintenance (S\&M) plan for Bldg. 3118.

\subsection{INTERNAL SPACES; NO ACCESS REQUIRED}

\subsubsection{Bldg. 3030 Hot Cell}

No deactivation activities related to Bldg. 3118 were conducted with respect to this hot cell. All hot cell deactivation activities were conducted as part of Bldg. 3030 deactivation. The hot cell access doors were closed and locked.

\subsubsection{Bldg. 3031 Hot Cell}

No deactivation activities related to Bldg. 3118 were conducted with respect to this hot cell. All hot cell deactivation activities were conducted as part of Bldg. 3031 deactivation. The hot cell access doors were closed and locked. 


\subsection{EXTERNAL SPACES}

\subsubsection{Bldg. 3118 Structure}

The exterior of Bldg. 3118 was inspected and found to be in generally good structural condition. The building exterior has been sealed to eliminate air inleakage and to provide effective containment for the building.

\subsubsection{Bldg. 3118 Roof}

The roof of Bldg. 3118 was inspected and found to be in generally good structural condition. The building exterior has been sealed to eliminate leakage and to provide effective containment for the building.

\subsection{OPERATIONAL SYSTEMS}

\subsubsection{Electrical Power System}

All electrical services (with the exception of lighting) that were not essential to the basic S\&M operations were disconnected at the main breaker box.

\subsubsection{Fire Protection System}

The fire protection system is a dry pipe delivery system and is available for use if there is a fire in the building.

\subsubsection{Hot Drain System}

The hot drains from the hot cells were plugged with a Plexiglas plug to isolate the hot cells and prevent the spread of contamination. No decontamination of the hot drain system has been performed.

\subsubsection{Process Drain System}

The process floor drains remain in operation to direct any roof inleakage to the ORNL process waste system and prevent any contamination from leaving the building. No decontamination of the process drain system has been performed.

\section{5 "MOTHBALLED" SYSTEMS}

No "mothballed" systems are associated with Bldg. 3118.

\subsection{ABANDONED SYSTEMS}

\subsubsection{Building Steam System}

The building steam system supply was drained and valved off. 


\subsubsection{Potable Water System}

The incoming line of the potable water system was capped to isolate the system from Bldg. 3118.

\subsubsection{Battery Charging Station}

The battery charging station was disconnected from the main breaker box.

\section{TRANSITION ACTIVITIES}

Building 3118 will be officially transferred from the DOE EM-60 program to the EM-40 program by a Memorandum of Agreement (MOA). The building will be accepted "as is" by EM-40 at the time of transfer.

\subsection{MEMORANDUM OF AGREEMENT}

The MOA documents the requirements agreed upon between EM-40 and EM-60. The signed MOA indicates acceptance by EM- 40 that the criteria outlined in the MOA have been completed satisfactorily, with the exception of post-transition punchlist items, and that the level of deactivation of the facility is acceptable for transition to the EM-40 program.

Post-Transition punchlist items will be finished after deactivation is complete using EM-60 funding. The details of how the punchlist items will be completed and documented are addressed in the MOA.

\subsection{POST-TRANSITION ACTIVITIES}

No Post-Transition punchlist items have been identified for Bldg. 3118. All deactivation activities have been completed prior to transfer to EM-40.

\section{POSTDEACTIVATION S\&M}

S\&M activities associated with the interior spaces, operational and mothballed systems, and external areas related to Bldg. 3118 are as follows:

1. Ensure adequate containment of contamination,

2. Provide physical safety and security control,

3. Maintain the facility in a manner that will minimize potential hazards to the public, and

4. Provide a mechanism for the identification and compliance with applicable environmental, safety, and health requirements. 
The operating procedure for Bldg. 3118 details the specific S\&M items to be performed. S\&M costs are based on previous operational costs associated with similar S\&M activities at ORNL.

The S\&M activities associated with Bldg. 3118 include the following types of activities:

- Walkdowns and inspections for structural integrity, safety, radioactive contamination, and hazardous material conditions;

- General housekeeping of the interior and exterior of the building as needed; and

- Maintenance activities required to maintain the security and safety envelope of the facility.

\section{ABNORMAL ACTIVITIES/CONDITIONS}

No Abnormal Activities/Conditions have been identified for Bldg. 3118 .

\section{TURNOVER PACKAGE DOCUMENTATION}

\subsection{ADMINISTRATIVE TURNOVER PACKAGE}

Administrative turnover consists of a collection of administrative documents. This includes procedures, agreements, and other documents directly related to the physical facility. The level of detail depends on the conditions, requirements, and agreements specific to the facility. Attachment 4, "Administrative Turnover Package Checklist," reflects the documents required for this facility with respect to administrative turnover. The following sections detail the contents of the applicable sections required for the facility.

\subsubsection{Final Deactivation Project Report}

The FDPR is a management summary of the facility deactivation completion and general status and conditions that demonstrating conformance with DOE's specification of the overall end point. It identifies nonroutine management actions needed. Unresolved issues are also described.

\subsubsection{Regulatory Compliance Documentation}

Regulatory compliance documentation addresses the status/compliance of all regulatory commitments; for example, status of compliance with applicable regulations promulgated pursuant to statutes, such as Occupational Safety and Health Administration, RCRA, CERCLA, and the National Environmental Policy Act and the remediation process in the National Contingency Plan.

\subsubsection{Interagency Agreements Documentation}

Interagency Agreements identify the terms and milestones of agreements pending and entered into by DOE with federal, state, and local agencies and the status of compliance. This includes settlement agreements, administrative or consent orders, and compliance plans to settle outstanding notices of violation. 


\subsubsection{Existing Permit Documentation}

Existing permit documentation addresses the status of existing permits, including National Pollutant Discharge Elimination System (NPDES), air permits, RCRA, and others associated with the facility.

\subsubsection{Corrective Action Documentation}

Corrective action documentation addresses the status of Corrective Actions completed and outstanding, from previous audits, inspections, and other similar activities (e.g., Tiger Team, Technical Safety Appraisal, Defense Nuclear Facility Safety Board, regulatory agencies, self assessments, business systems review), including identification of those items that need to reevaluated and reviewed with respect to the facility's surplus condition.

\subsubsection{Deactivation Locks and Keys}

The deactivation locks and keys system monitors facility access, isolation of electrical components, chaining of valves, and other situations where physical access is to be controlled. The primary purpose of this system is to ensure control as the work force "backs out" of the facility as specified end points are achieved.

\subsection{TECHNICAL TURNOVER PACKAGE}

Technical turnover consists of a collection of technical documents that describe the facility, its equipment, and the conditions at the completion of all deactivation activities. The level of detail depends on the conditions, requirements, and agreements specific to the facility. Attachment 5 , "Technical Turnover Package Checklist," reflects the documents required for this facility with respect to technical turnover. The following sections detail the contents of the applicable sections required for the facility.

\subsubsection{Updated Facility Drawings (Arrangement, PID, Loop, Etc.)}

Updated facility drawings include facility, room, and cell arrangement drawings- to the extent they exist. However, except in unique circumstances, as-builts of the deactivated conditions within the facility are not provided.

Facility drawings provide status (including drawings) of the deactivation/safe shutdown (if applicable). The documentation addresses systems, such as the water, sewer, air, electric, gas, process (mechanical and chemical), and fire protection systems. Table 7 lists updated drawings for Bldg. 3118. Attachment 6 contains the drawing list for Bldg. 3118.

Table 7. Bldg. 3118 Updated Drawings

\begin{tabular}{ccl}
\hline Number & Rev. & \multicolumn{1}{c}{ Title } \\
\hline H21132EG-007-D & & $\begin{array}{l}\text { AC Elect. Struct. Plan Sects. Dets. AC Units } \\
\text { Isotope AR }\end{array}$ \\
H3E-20011-G025 & A $\quad \begin{array}{l}\text { RWFI-Isotope Area - Bldg. 3118 Roof Plan, } \\
\text { Cell Vent. \& Off-Gas }\end{array}$ \\
\hline
\end{tabular}




\subsection{2 "As Left" Photos of Spaces and Major Equipment}

"As Left" photos include description/photos of spaces for which access is not anticipated during S\&M.

\subsubsection{Hazardous Material Inventory and Survey}

The Hazardous Material Inventory and Survey addresses the location of fixed hazardous materials, wastes, and contamination with characterization information.

\subsubsection{Safeguards and Security Documentation}

Safeguards and security documentation provides for nuclear or other material remaining in the facility for which there is a requirement for accountability or protection from diversion.

\subsubsection{Chemical Substance Inventory and Survey}

The chemical substance inventory and survey inventories chemical and hazardous substances remaining, if any, and addresses characterization information.

\subsubsection{Radioactive Materials Inventory and Survey}

The radioactive materials inventory and survey addresses inventory of radioactive and fissile material remaining as contamination with characterization information, final radiological/hazardous materials survey records, final configuration and $S \& M$ requirements, available drawings, specifications, procedures, manuals, and unplanned occurrences records applicable to the facility. Attachment 7 contains radiological survey data.

\subsubsection{Facility Soil, Surface Water, and Groundwater Condition Report}

The Facility Soil, Surface Water, and Groundwater Condition Report provides all available data for those media, describes those conditions and the nature and extent of contamination therein, and identifies any known assessment requirements.

\subsection{S\&M TURNOVER PACKAGE}

S\&M turnover consists of a collection of documents required to support postdeactivation S\&M activities. The level of detail depends on the S\&M specific to the facility. Attachment 8, "S\&M Turnover Package Checklist," reflects the documents required for this facility with respect to S\&M turnover. The following sections detail the contents of the applicable sections required for the facility.

\subsubsection{Postdeactivation S\&M Plan}

The Postdeactivation S\&M Plan describes the S\&M plan for the facility after deactivation is complete, up to the initiation of decommissioning. S\&M activities will be integrated into the decommissioning work and phased out as decommissioning is completed. 


\subsubsection{Postdeactivation S\&M Updated Safety Equipment List}

The Postdeactivation S\&M Updated Safety Equipment List describes the safety equipment that will remain in the facility during the postdeactivation S\&M period.

\subsubsection{Postdeactivation S\&M Procedures}

The "Building 3119 Facility Procedure" is to be followed during the postdeactivation S\&M period. This procedure outlines the maintenance activities and special surveillances required to ensure that the facility conditions and safety envelope remain consistent until decommissioning can take place.

\section{ASSOCIATED LITERATURE}

Document Number

DOE/EM-0246

ORNL/ER-249/R2

\section{Document Title}

Decommissioning Resource Manual. August 1995

Martin Marietta Environmental Restoration Program; Work Plan for the Isotopes Facilities Deactivation Project at Oak Ridge National Laboratory, August 1995

Oak Ridge National Laboratory; Local Emergency Manual, Isotope Area, Revision 94-1, January 1994

\section{ATTACHMENTS}

1. Bldg. 3118 Floor Plan

2. Bldg. 3118 Predeactivation Facility Photographs

3. Bldg. 3118 Postdeactivation Facility Photographs

4. Administrative Turnover Package Checklist

5. Technical Turnover Package Checklist

6. Bldg. 3118 Drawing List

7. Bldg. 3118 Radiological Survey Data

8. S\&M Turnover Package Checklist 

ATTACHMENT 1

BLDG. 3118 FLOOR PLAN 

ORNL DWG 97C-257

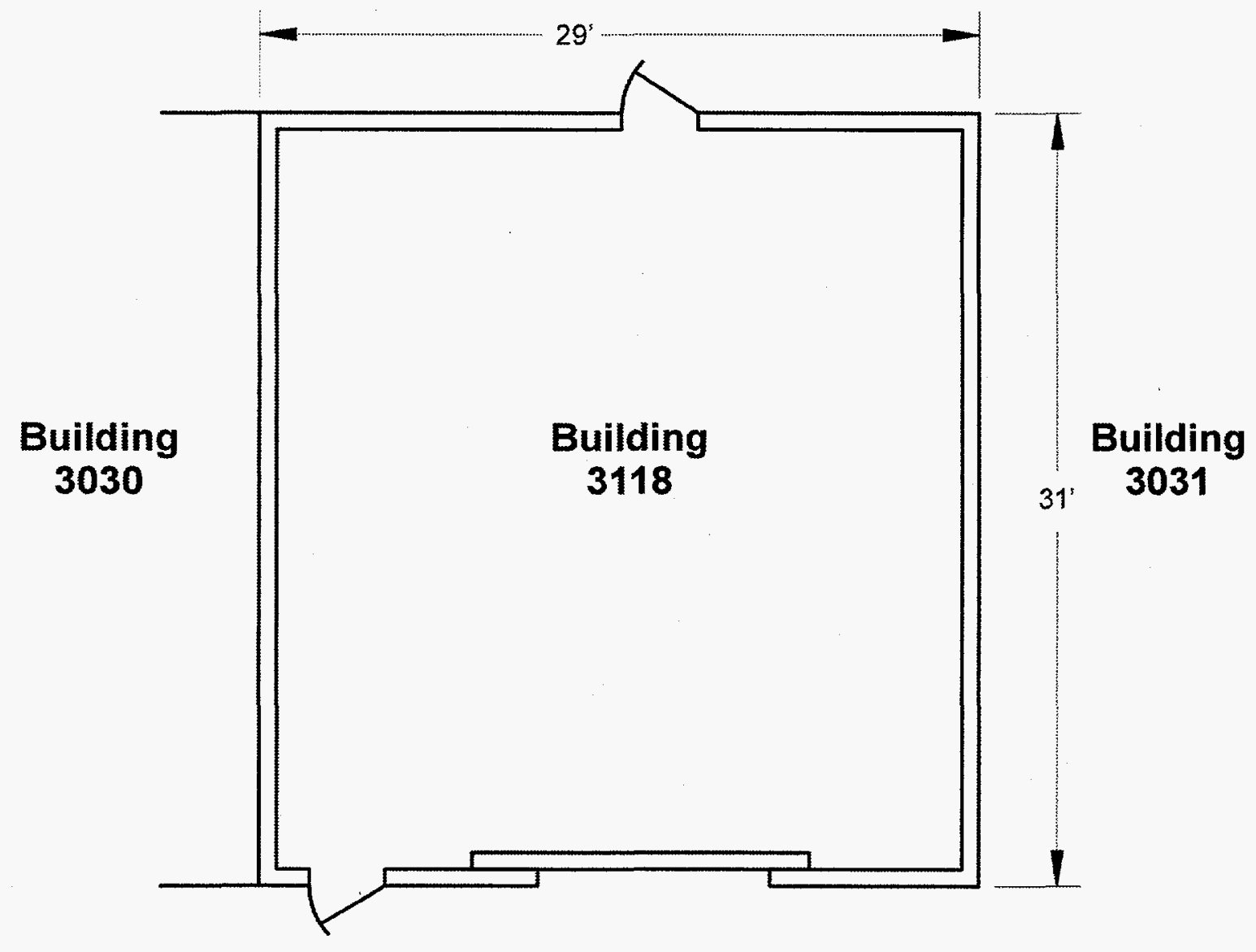



ATTACHMENT 2

BLDG. 3118

PREDEACTIVATION FACILITY PHOTOGRAPHS 



\section{2-3}

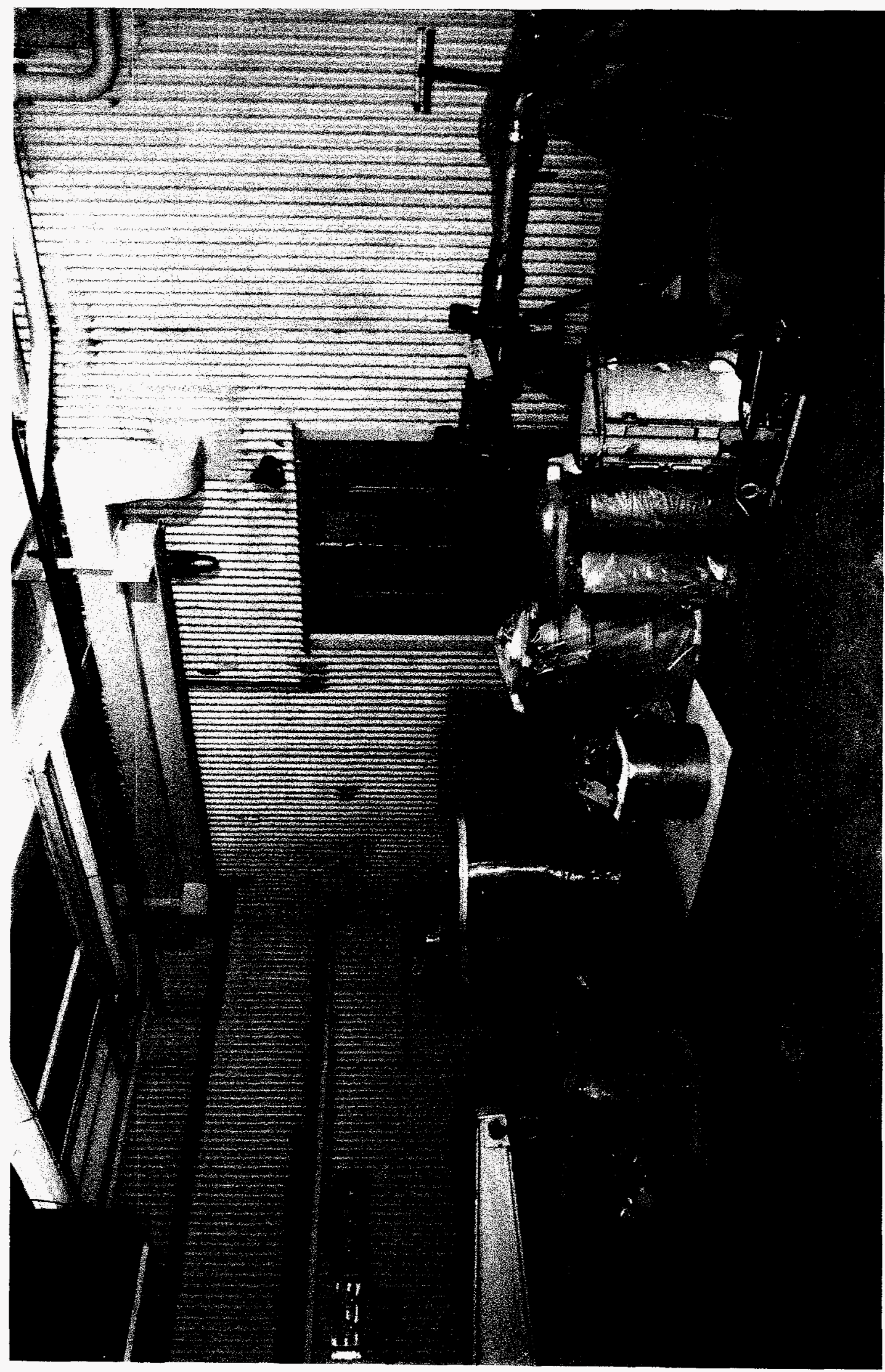

: 


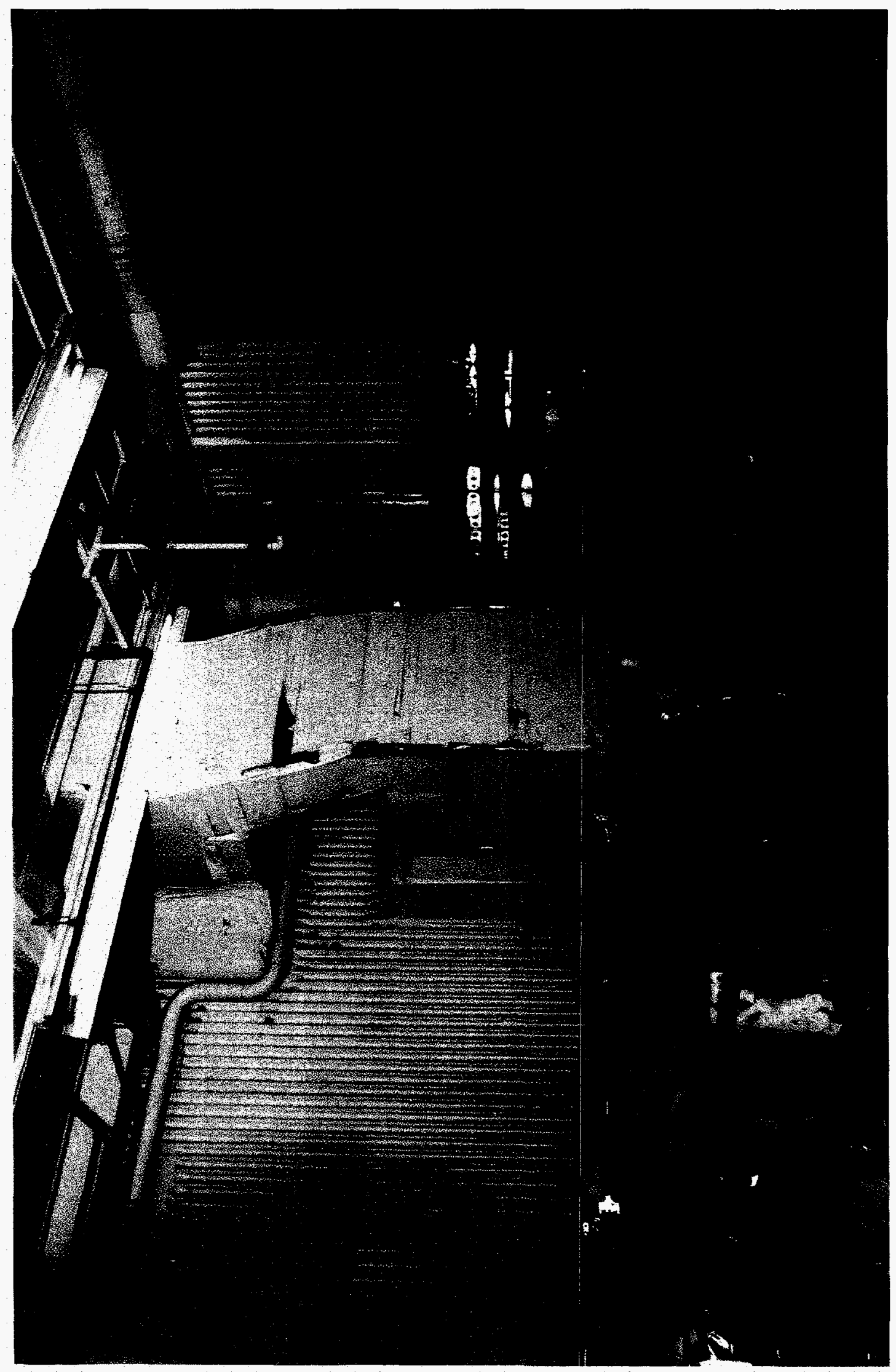

营 


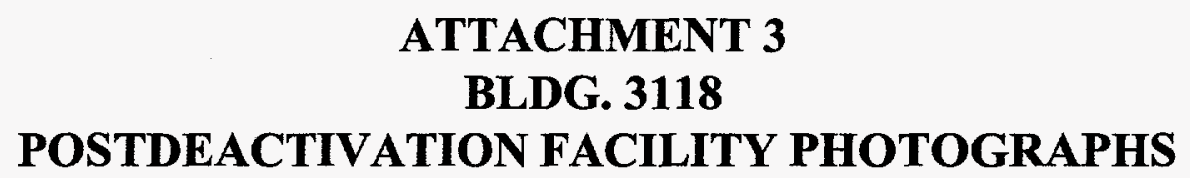





\section{3-3}

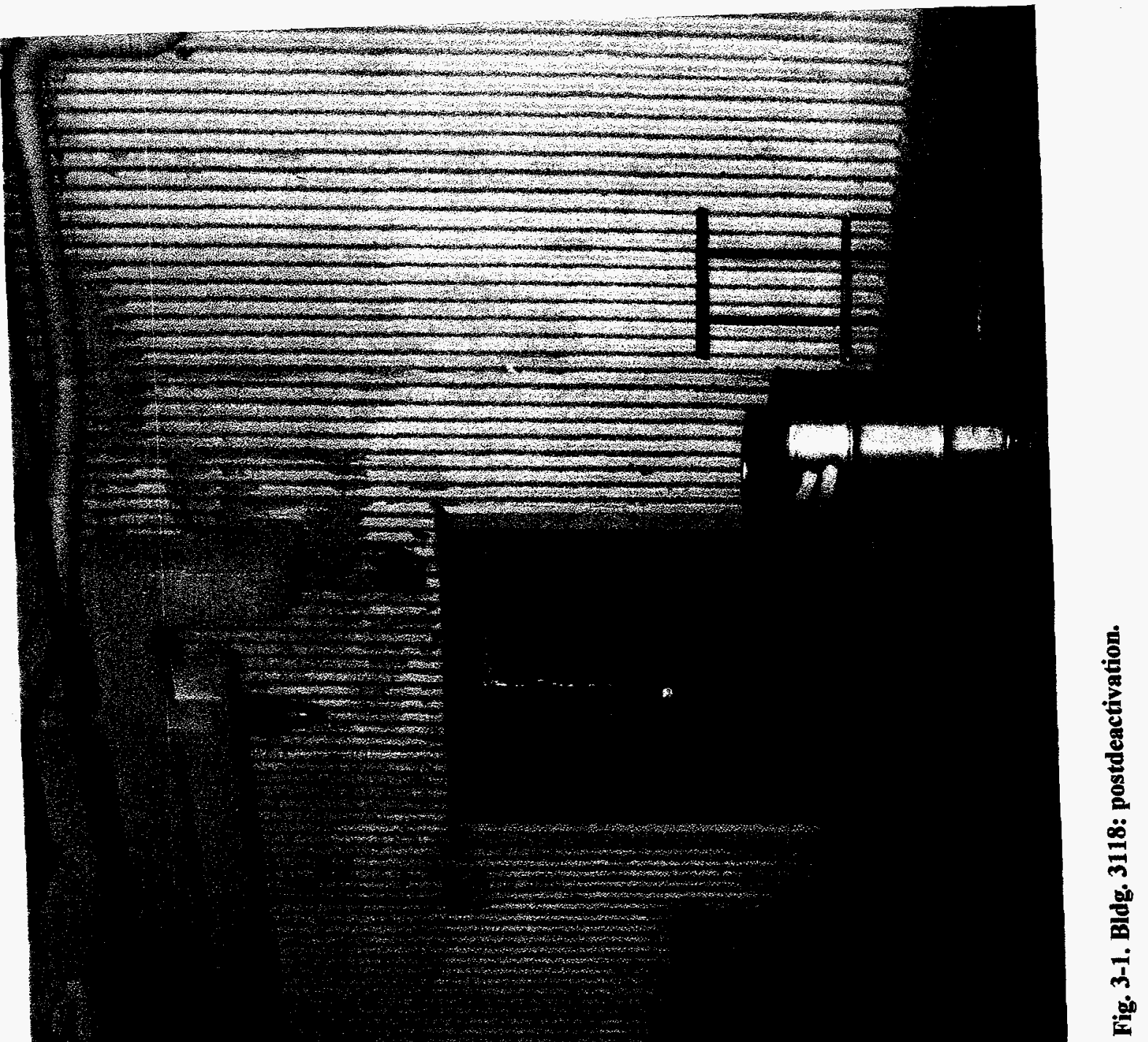




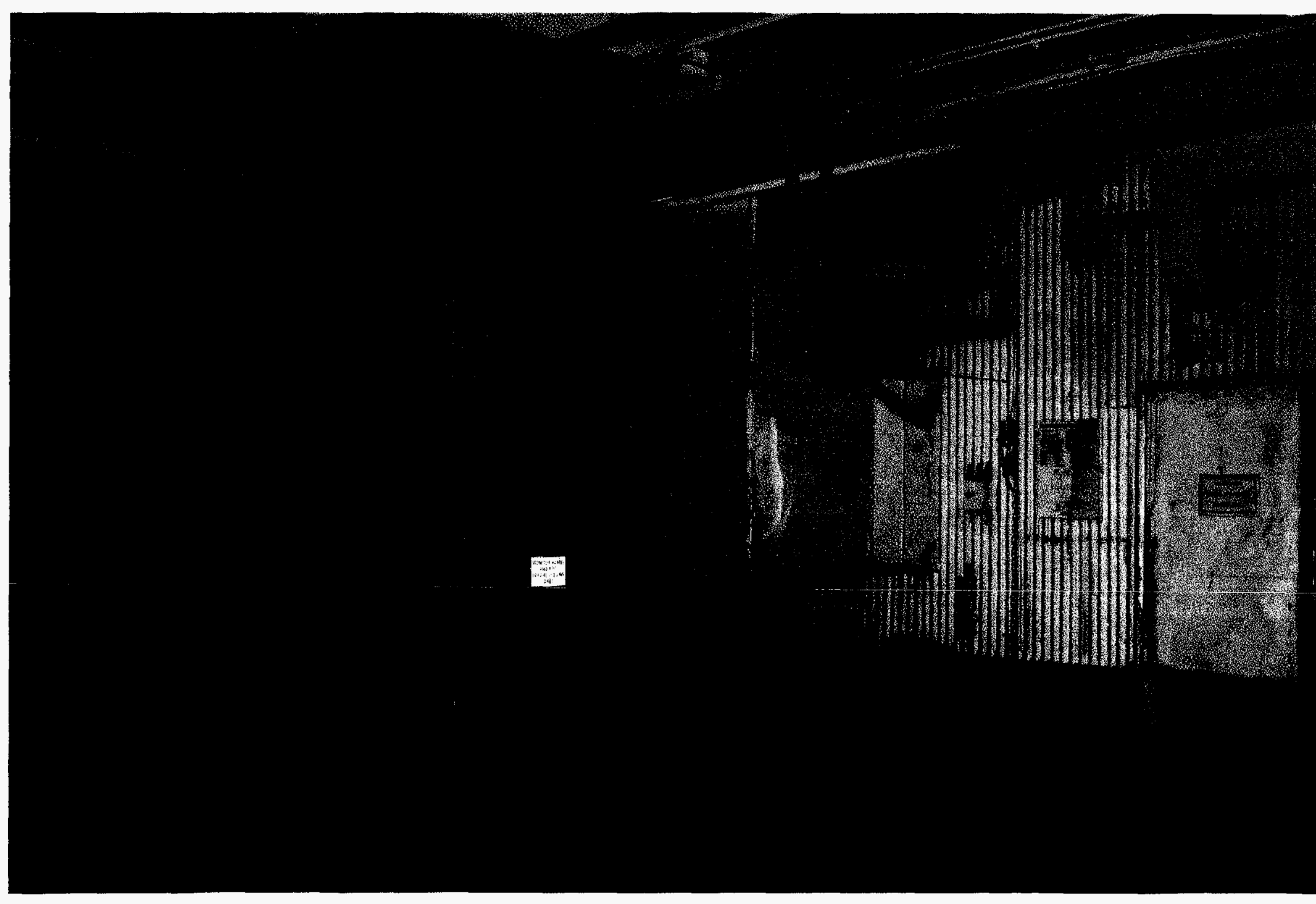

Fig. 3-2. Bldg. 3118: postdeactivation. 
ATTACHMENT 4

ADMINISTRATIVE TURNOVER

PACKAGE CHECKLIST 

Administrative Turnover Package Checklist

\begin{tabular}{clc}
\hline Item Number & \multicolumn{1}{c}{ Document } & Applicable ? \\
\hline 1 & FDPR & Yes \\
2 & Emergency Response Plan & No \\
3 & Safety Documentation (Category III or greater) & No \\
4 & Regulatory Compliance Documentation & No \\
5 & Interagency Agreements Documentation & No \\
6 & Existing Permit Documentation & No \\
7 & Corrective Action Documentation & No \\
8 & Postdeactivation Punchlist & No \\
9 & Deactivation Locks Log and Keys & Yes \\
\hline
\end{tabular}



ATTACHMENT 5

TECHNICAL TURNOVER

PACKAGE CHECKLIST 

Technical Turnover Package Checklist

\begin{tabular}{clc}
\hline Item Number & \multicolumn{1}{c}{ Document } & Applicable ? \\
\hline 1 & End Point Determination Report & No \\
2 & End Points Completion Report & No \\
3 & End Point Technical Information & No \\
4 & Deactivation Work Plans & No \\
5 & Updated Facility Drawings (arrangement, PID, Loop, etc.) & Yes \\
6 & "As Left" Photos of Spaces and Major Equipment & Yes \\
7 & Hazardous Material Inventory and Survey & Yes \\
8 & Safeguards and Security Documentation & Yes \\
9 & Chemical Substance Inventory and Survey & Yes \\
10 & Radioactive Materials Inventory and Survey & Yes \\
11 & Facility Soil, Surface Water, and Groundwater Condition & No \\
\hline
\end{tabular}



ATTACHMENT 6

BLDG. 3118

DRAWING LIST 

Bldg. 3118 Drawing List

\begin{tabular}{lll}
\hline \multicolumn{1}{c}{ Document Number } & Revision & \multicolumn{1}{c}{ Title } \\
\hline C3E-020366-A001 & & $\begin{array}{l}\text { Reroof Bldgs. 3030, 3118, and 3031 - Site Access Plan } \\
\text { and Drawing Index }\end{array}$ \\
& & $\begin{array}{l}\text { AC Elect. Struct. Plan Sects. Dets. AC Units Isotope } \\
\text { AR }\end{array}$ \\
H21132EG-007-D & A & $\begin{array}{l}\text { RWFI-Isotope Area - Bldg. 3118 Roof Plan, Cell } \\
\text { Vent. \& Off-Gas }\end{array}$ \\
H3E-20011-G025 & A & $\begin{array}{l}\text { RWFI-Isotope Area - Bldg. 3118 Attic Plan, Sections } \\
\text { \& Details }\end{array}$ \\
H3E-20011-G034 & & $\begin{array}{l}\text { Reroof Bldgs. 3030, 3118, 3031 - Roof Plan, Sections } \\
\text { \& Details }\end{array}$ \\
S3E-020366-B012 & & Reroof Bldgs. 3030, 3118, 3031 - Sections \& Details \\
& &
\end{tabular}





\section{ATTACHMENT 7}

BLDG. 3118

RADIOLOGICAL SURVEY DATA 



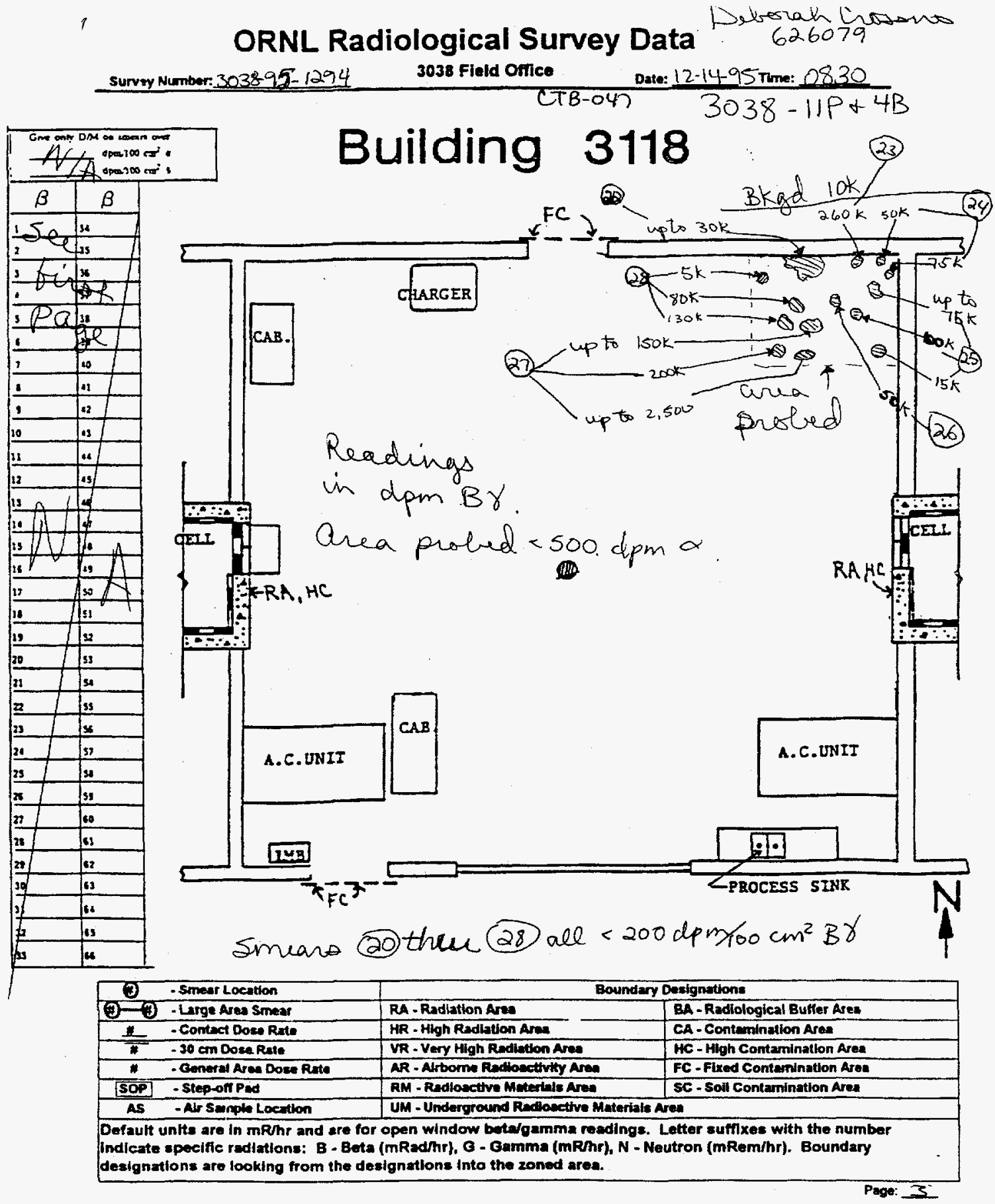




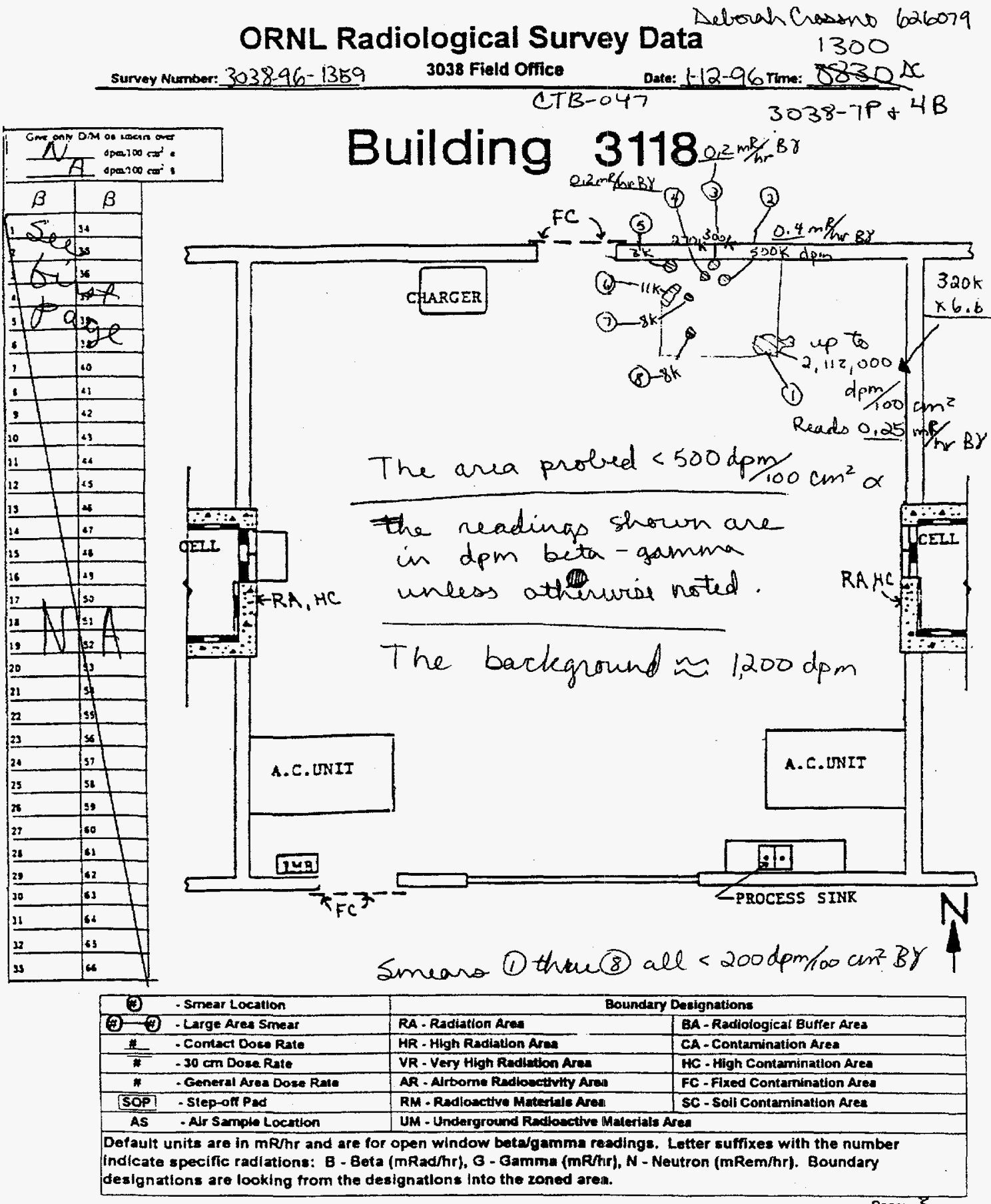

Page: 3 


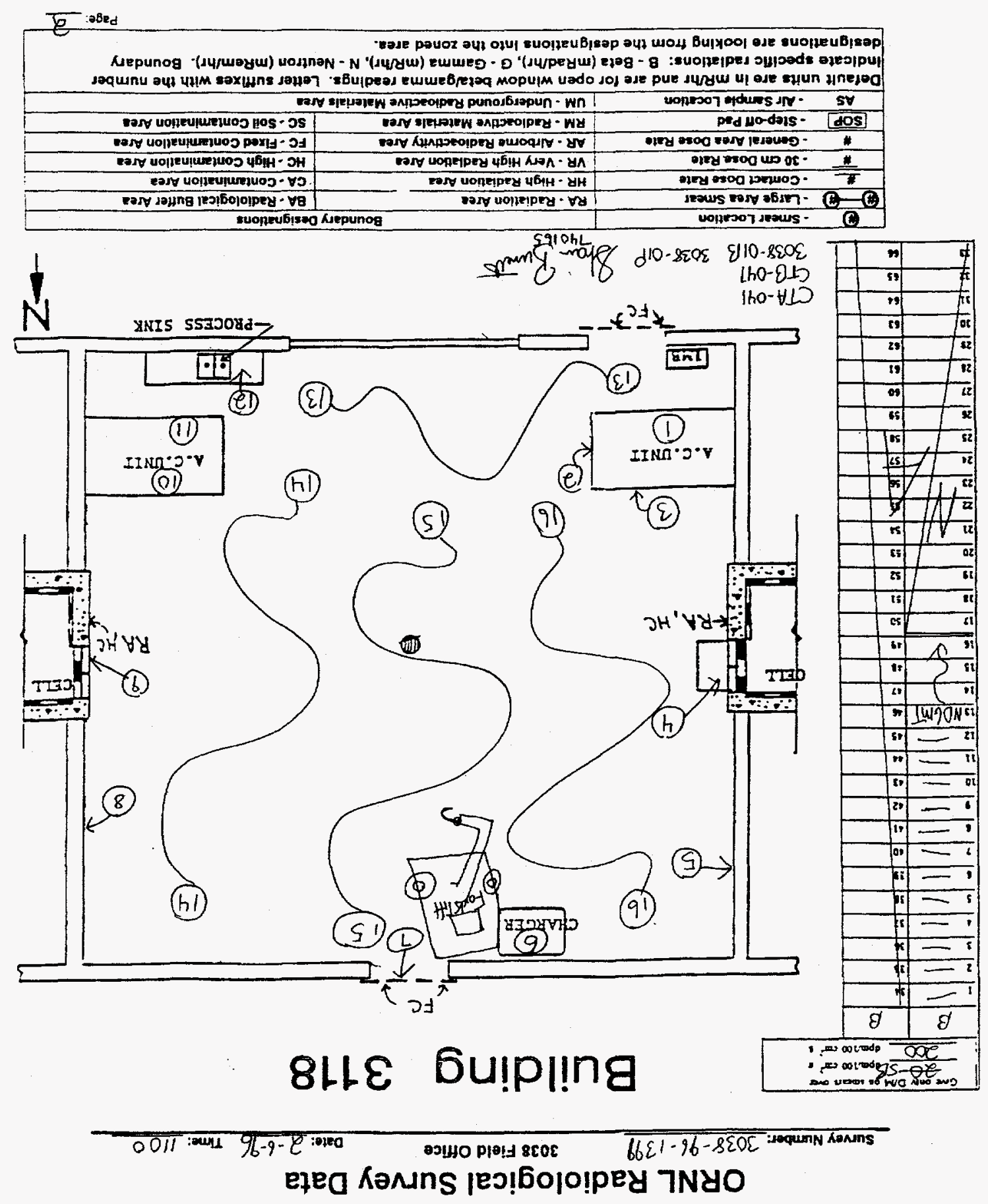




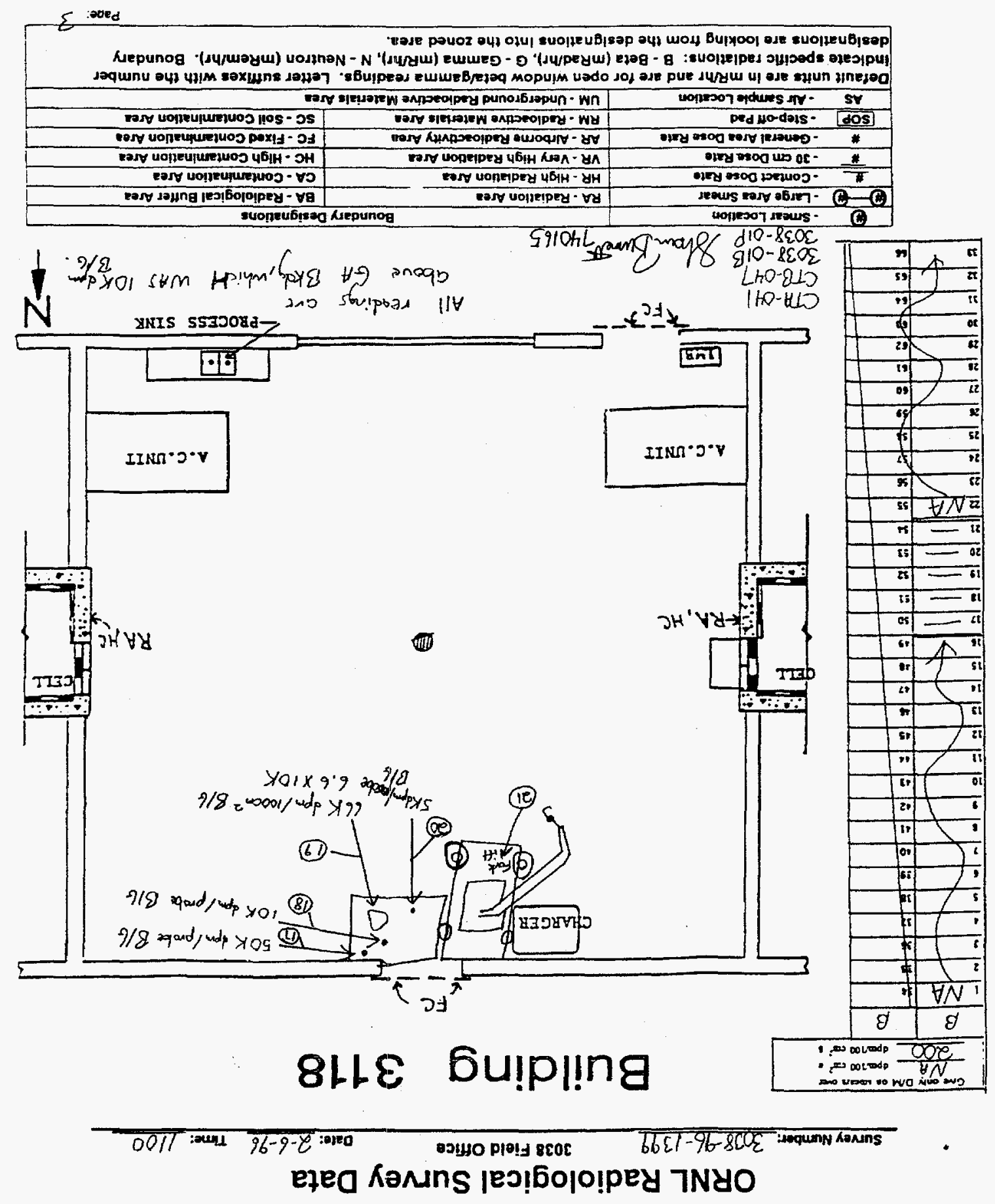




\section{ORNL Radiological Survey Data}

Surveyor Badge Number: 34667 Routine Survey RWP Number:

Building: $2400731 / 8$ Specific Location: FLOOR AREA ADJACENT TO WEST CELL.

Description:

PERFORMED NON-ROUTINE RADIATION / CONTAMINATION SURVEY OF FLOOR AREA UNDERNEATH THE LEAD SHIELDING.

Instruments Used and Calibration Due Date:

3038-1P 8/26/96 CTA-041

Coneral Description of Padiologicel Conditions:

MAXIMUM DOSE RATES WERE 70 MR/HR @ CONTACT / 11 MR/HT @ 1 FOOT. AVERAGE WHOLE BODY DOSE RATE IN FRONT OF CELL - 4 MR/HR. AVERAGE DOSE RATE @ CONTACT WITH FLOOR 8 MR/HR. TRANSFERABLE CONTAMINATION OF UP. TO 725 DPM DETECTED ON EYEBOLT \& SURROUNDING CONCRETE SURFACES OF HOLE. MULTIPLE DECON ATTEMPTS FAILED TO BRING LEVELS DOWN BELOW 200 DPM. COVERED EYEBOLT \& HOLE WITH CONTAMINATION AREA TAPE. LEAD SHIELDING PUT BACK IN PLACE AT END OF SURVEY.

Division or Group Needing the Survey: $\quad$ CHEM TECH.

Person-hours epent on the survey: 3

\begin{tabular}{|c|c|c|c|c|c|c|c|c|c|c|c|}
\hline \multicolumn{12}{|c|}{ Smear Results (dpm/100 $\mathrm{cm}^{2}$ unless noted) } \\
\hline \begin{tabular}{|c|} 
Smear \\
Number
\end{tabular} & $\alpha$ & $\boldsymbol{\beta}$ & Loention & $\begin{array}{l}\text { Smear } \\
\text { Number }\end{array}$ & $\alpha$ & $\boldsymbol{\beta}$ & Location & $\begin{array}{c}\text { smear } \\
\text { Numbar }\end{array}$ & $\alpha$ & $\beta$ & Location \\
\hline 1 & NC & 5,000 & $\begin{array}{l}\text { LARGE AREA } \\
\text { MUSSIN- SEE } \\
\text { MuP. }\end{array}$ & 23 & NC & ND/GMT & $\begin{array}{l}\text { LAROE AREA } \\
\text { MASSLN-SEE } \\
\text { MMP. }\end{array}$ & 4 & NC) & ND/GMT & $\begin{array}{l}\text { RE } M \text { MSSLIN OF - } \\
\text { AFTER DECON- } \\
\text { SEE MMP. }\end{array}$ \\
\hline $5-10$ & $<20$ & $<200$ & SEE mW. & 11 & $<20$ & 620 & $\begin{array}{l}\text { SARAN OF EYE- } \\
\text { BOLT' } \\
\text { CoNChETE - SEE } \\
\text { MMP. }\end{array}$ & 12 & $<20$ & 725 & $\begin{array}{l}\text { RESMEAR OF } \\
\text { AFTER INITAL } \\
\text { OESCON ATTEMPT. }\end{array}$ \\
\hline 13 & $<20$ & 300 & 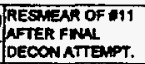 & 14-17 & $<20$ & $<200$ & $\begin{array}{l}\text { LEAD SHELDNHO } \\
\text { EROM FIOOR. }\end{array}$ & & & & \\
\hline
\end{tabular}



A radiation area was set uf after this survey, until lead replaced.

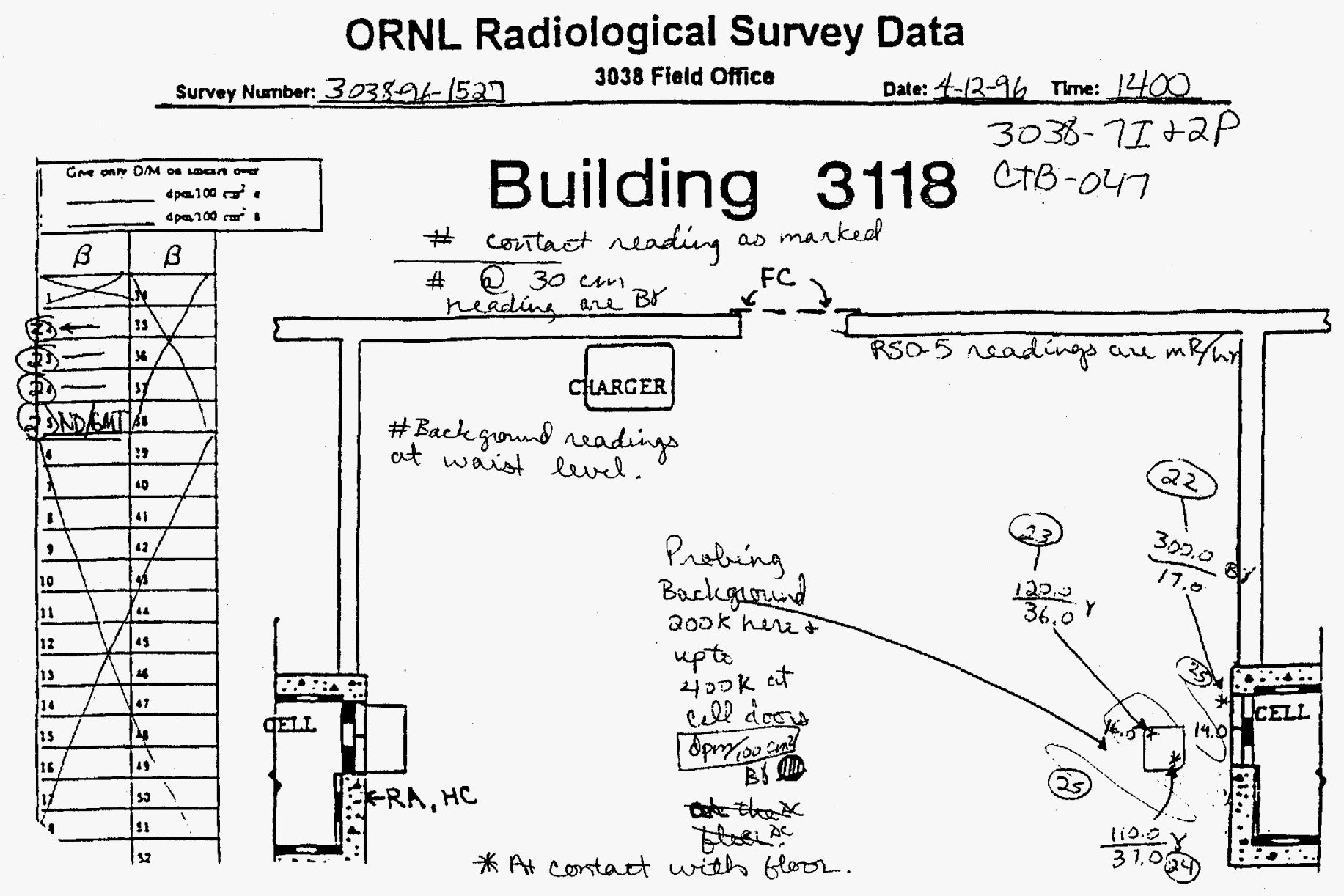




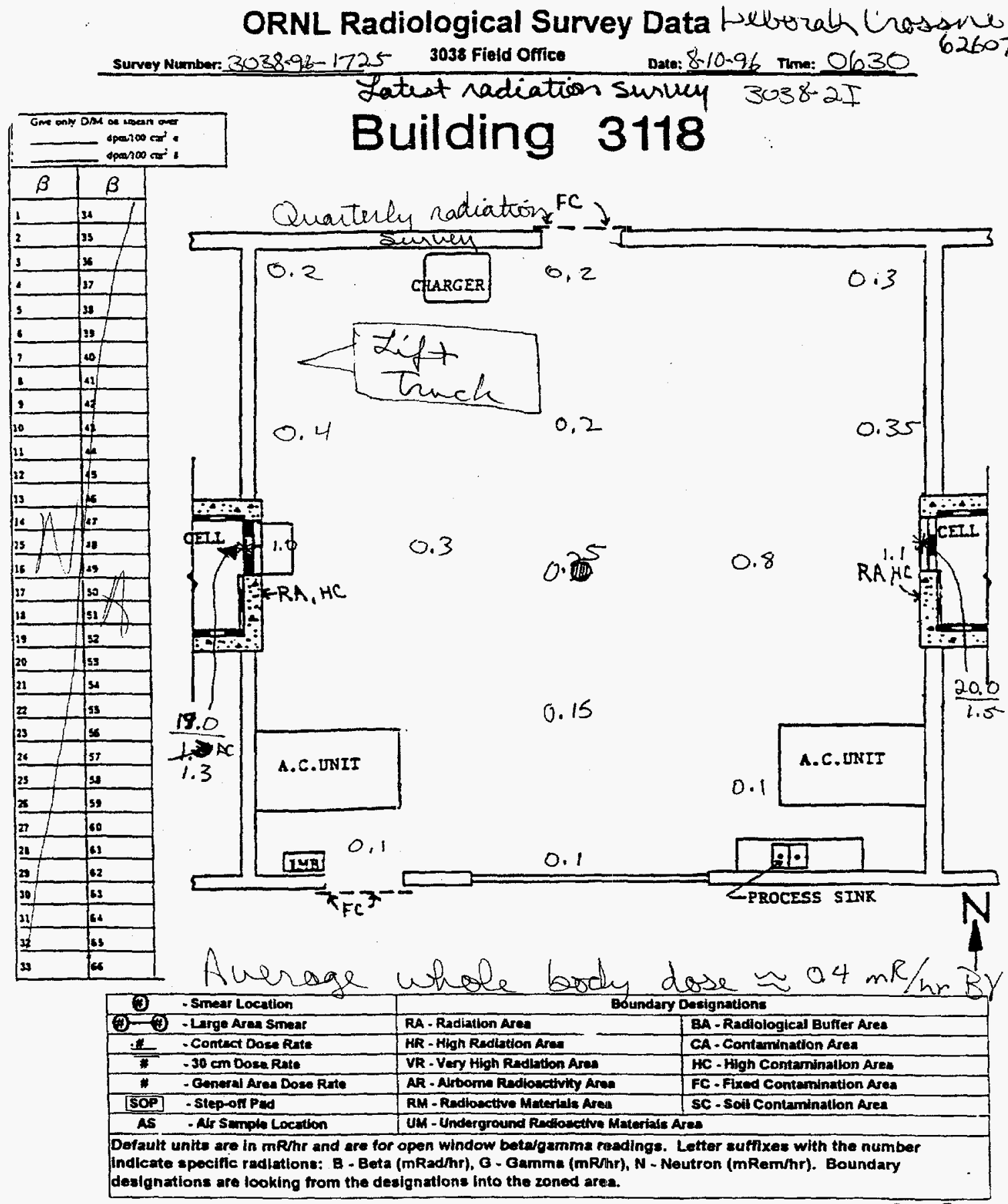


ORNL Radiological Survey Data 626079 Survey Number:3038-97-0132 3038 Field Ofilce Date: 2-14-97 Time: 0900

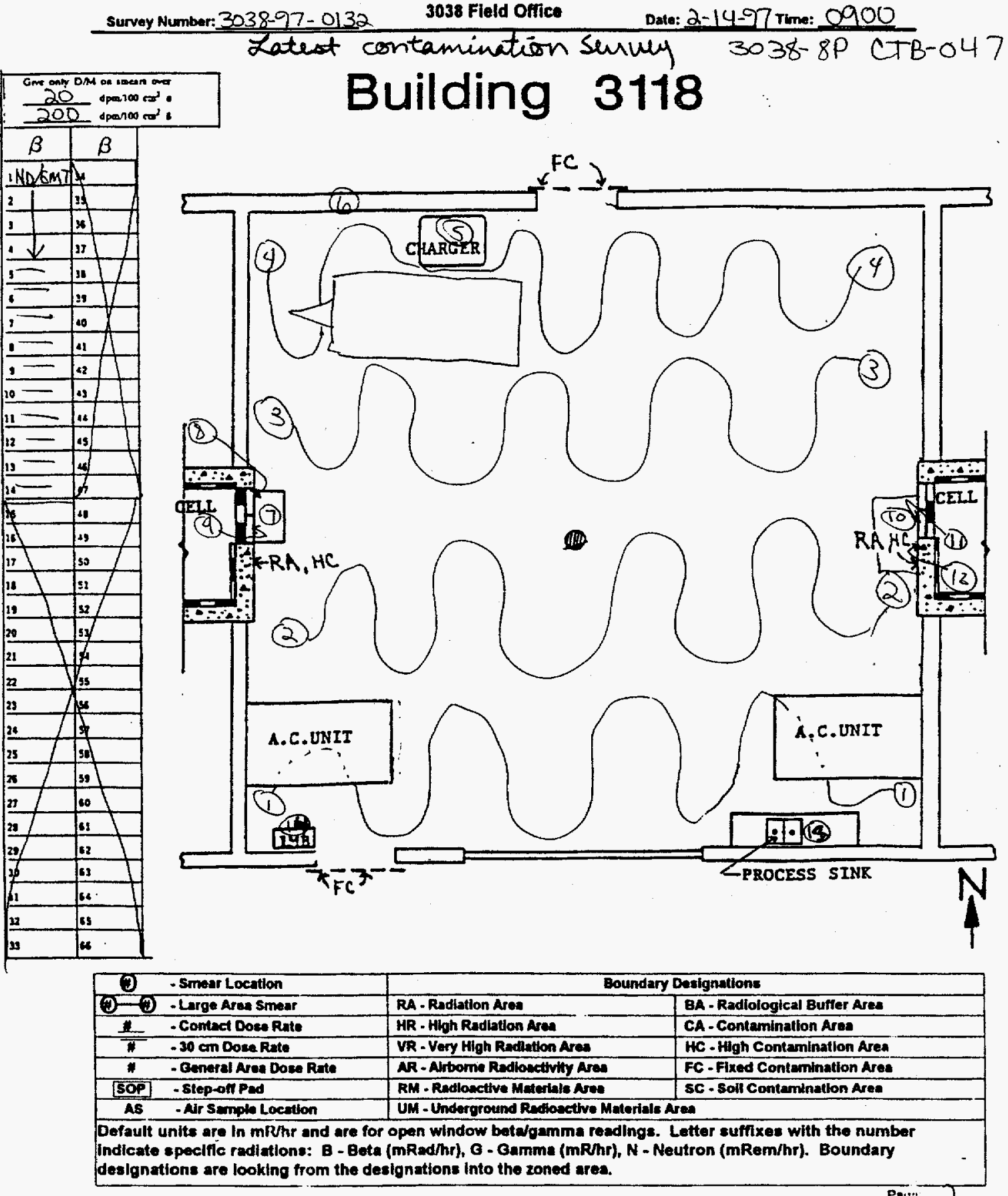

Pey= 2 



\section{ATTACHMENT 8 \\ S\&M TURNOVER \\ PACKAGE CHECKLIST}





\begin{tabular}{clc}
\hline $\begin{array}{c}\text { Item } \\
\text { Number }\end{array}$ & \multicolumn{1}{c}{ Document } & Applicable ? \\
\hline 1 & Postdeactivation S\&M Plan & Yes \\
2 & Postdeactivation S\&M Updated Effluent Monitoring Plan & No \\
3 & Postdeactivation S\&M Updated Safety Equipment List & Yes \\
4 & Postdeactivation S\&M Procedures & Yes \\
5 & Postdeactivation S\&M Recommendations & No \\
6 & Mothballed Systems Lay-up and Restart Documentation & No \\
\hline
\end{tabular}





\section{DISTRIBUTION}

1. L. V. Asplund

2. W. D. Brickeen

3. R. A. Brown

4. T. W. Burwinkle

5. K. Constant

6-15. R. E. Eversole

17. K. W. Haff

18. S. A. Herron

19. L. L. Kaiser

20. T. M. Koepp

21. P. T. Owen

22. L. D. Owens

23. B. D. Patton

24. L. B. Raulston

25. Central Research Library

26. File-EMEF DMC-RC 
